\title{
Eğitim Konulu Filmlerin Sınıf Yönetiminin Boyutları Açısından incelenmesi*
}

\author{
Emrullah AKCAN', Mevlüt KARA ${ }^{2}$
}

\begin{abstract}
Öz: Bu araştırmada Millı̂ Eğitim Bakanlığı'nın (MEB) Eylül 2018 dönemi mesleki çalışma programı kapsamında öğretmenlerin izlemesi için önerdiği filmlerin sınıf yönetiminin boyutları açısından incelenmesi amaçlanmıştır. Bu amaç doğrultusunda MEB tarafından önerilen 50 film arasından sınıf içi uygulamaların en yoğun sahnelendiği dört film ölçüt örnekleme tekniği ile seçilmiştir. Nitel olarak tasarlanan bu araştırmada verilerin elde edilmesinde doküman incelemesi; çözümünde betimsel analiz tekniğinden yararlanılmıştır. Araştırma sonucunda, filmlerde sınıf yönetimi açısından öğrencilerin tek kişilik sıralarda oturması, öğretmenlerin derse hazırlıklı ve öğrenciden önce gelmesi, öğrencilere ismi ile hitap etmesi ve sakin, samimi, nezaket kurallarına dikkat eden bir yapıda olmaları gibi olumlu özelliklerin ön plana çıtığı belirlenmiştir. Diğer yandan öğretmen tarafından sınıfın seviyesine uygun olmayan bir metnin okutulması, dersin plansız bir şekilde işlenmesi ve tepkisel sınıf yönetimi modelinin benimsenerek ceza yöntemine başvurulması ise sınıf yönetimini olumsuz etkileyen davranışlar olarak tespit edilmiştir. Filmlerde sınıf yönetimi açısından ortaya çıkan olumlu ve olumsuz davranışlar, öğretmenlik grubu lisans öğrencilerine "Sınıf Yönetimi” derslerinde uygulamalı örnekler olarak sunulabilir.
\end{abstract}

Anahtar Sözcükler: Eğitim filmleri, Sınıf yönetimi, Doküman analizi

\section{The Examination of Education-Related Movies in Terms of Classroom Management}

\begin{abstract}
This study aimed to examine the movies recommended by the Ministry of National Education MEB [MoNE]) for the teachers to watch within the scope of the September 2018 professional study program in terms of the dimensions of classroom management. For this purpose, using the criterion sampling technique, the four movies in which classroom practices were most intensely displayed were selected among the 50 movies recommended by the MoNE. Designed as a qualitative study, the study used document analysis to collect data and the descriptive analysis technique to analyze the data. As a result of the study, it was determined that the positive features such as the students' seating arrangement in single rows, the teachers being prepared for the lessons, arriving class before the students, addressing the students by their names, and being calm, sincere and paying attention to the rules of courtesy were highlighted in terms of classroom management. On the other hand, the teaching of a text that is not suitable for the level of the class, the unplanned teaching of the lesson, and the use of punishment method by adopting the reactive classroom management model were listed to be the behaviours that negatively affect the classroom management. Behavioural patterns in movies - either positive or negative in terms of classroom management - can be presented to undergraduate students in the Faculty of Education as practical examples during "Classroom Management" courses.
\end{abstract}

Keywords: Educational movies, Classroom management, Document analysis

\footnotetext{
Geliş Tarihi: 31.05.2021

Kabul Tarihi: 19.08.2021

Makale Türü: Araştırma Makalesi

* Bu çalışma 16-20 Ekim 2019 tarihlerinde düzenlenen 18. Sınıf Öğretmenliği Eğitimi Sempozyumu'nda (USOS) sözlü bildiri olarak sunulmuştur.

1 Gaziantep Üniversitesi, Nizip Eğitim Fakültesi, Temel Eğitim Bölümü, Gaziantep, Türkiye, e-posta: emrullahakcan@gantep.edu.tr, ORCID: https://orcid.org/0000-0002-5492-4159

2 Gaziantep Üniversitesi, Nizip Eğitim Fakültesi, Temel Eğitim Bölümü, Gaziantep, Türkiye, e-posta: mevlutkara85@gmail.com, ORCID: https://orcid.org/0000-0002-6381-5288
} 
Sınıf, eğitim sistemi içinde, eğitim-öğretim etkinliklerinin gerçekleştirildiği en küçük birim olarak tanımlanabilir. Sınıfta eğitim-öğretim etkinliklerinden sorumlu olan öğretmen, eğitsel hedeflere ulaşabilmek ve sınıfı uygun hale getirmek için çeşitli düzenlemeler yapar. Bunun için öğretmenlerin etkili sınıf yönetimi becerilerine sahip olmaları gerekir. Kısaca sınıf yönetimi, sınıfta öğrenme etkinliklerine uygun bir atmosferin oluşturulması için, sınıfın fiziksel düzenlemelerinin yanında, zaman yönetimi, sınıf kuralları, öğrenciöğretmen; öğrenci-öğrenci ilişkileri, öğrencinin güdülenmesi gibi konuları kapsamaktadır (Karip, 2017). Balyer (2018), sınıf yönetimini tanımlarken, öğretmen tarafından koşulların hazırlanması ve sürdürülmesine değinmiştir. Mac Donald ve Healy (1999) de kendi tanımlarında, sınıf yönetimini; öğretmenin kendi yetenekleri ile sınıftaki öğrencileri öğrenme ortamına sokmak olarak ifade etmişlerdir. Bu açıdan düşünüldügünde, eğitim hedeflerine ulaşabilmek için öğretmenin etkili sınıf yönetim becerilerine sahip olması gerektiği söylenebilir.

Etkili bir sınıf yönetiminin asıl amacının, sınıf içi eğitim-öğretim etkinliklerinde, öğretmen ve öğrenci etkileşimini engelleyebilecek olası sorunların önlenmesi veya ortaya çıkan sorunların çözümü, verimli zaman yönetimi ve diğer sınıf içi eğitim-öğretim faaliyetlerine öğrencilerin aktif katılımı şeklinde olduğu düşünülebilir. Bu doğrultuda sınıf yönetimi, sınıf ortamında etkili ve verimli bir öğrenme iklimi oluşturabilmeyi amaçlar (Bakioğlu, 2009; Sadık, 2000; Sayın, 2001;). Ancak bu iklimi gelişigüzel, plansız bir şekilde oluşturabilmek mümkün değildir. Yönetim işi çok boyutludur, dolayısıyla sınıf yönetimini de oluşturan boyutlar vardır. Alanyazın incelendiğinde, sınıf yönetimini oluşturan beş boyuta değinildiği görülmektedir (Aydın, 2017; Akcan, 2018; Balyer, 2018). Bu boyutlar; sınıfın fiziksel düzenlemeleri, planprogram etkinlikleri, zaman yönetimi, ilişki düzenlemeleri ve davranış düzenlemeleri olarak sıralanmaktadır.

Sınıfın fiziksel düzenlemeleri; sınıfın 1Sı, ışık, gürültü, duvar süslemeleri, sıra düzeni, öğrenci mevcudu gibi unsurlardan oluşur ve eğitim-öğretim faaliyetlerinin büyük kısmı bu ortamda gerçekleştiği için öğrenme üzerinde doğrudan etki eder (Akcan, 2018). Fiziksel düzenleme denilince akla sadece sıra düzeni, 1sı, ışık düzeyi gelmemelidir. Aynı zamanda, öğretmenin sınıfta konumlandığı nokta, yazı tahtasının yeri, öğrencilerin rahat hareket edebilecekleri alan durumu, motivasyon arttırıcı veya dikkat dağıtıcı unsurların tamamı sınıfın fiziksel değişkenleri arasında sayılabilir. Sınıf yönetiminin bir diğer boyutu olan planprogram etkinlikleri; bazı kaynaklarda öğretimin yönetilmesi olarak da tanımlanmaktadır (Aydın, 2017; Akcan, 2018). Öğretimin yönetimi genel olarak, eğitim ortamı ile öğretimde hedeflenen amaçların bütünleştirilmesini ifade eder. Daha yalın bir anlatımla, öğretimin yönetilmesi; kazandırılması hedeflenen davranış örüntüleri ile bu hedeflere ulaşmada kullanılan yöntem, teknik, araç-gereç, ders içi uygulamalar, dönüt-düzeltme-değerlendirme, pekiştirme, güdüleme gibi faktörlerden oluşur. Zaman yönetimi boyutu; öğretmenin bir (1) ders saatinde hedeflediği amaçlara ulaşıp ulaşmadığı ile ilgilidir. Kısaca, sınıfta ders süresinin verimli bir şekilde kullanılması, etkili bir öğretim yapıldığının da işareti sayılabilir. Bu beceri de bir öğretmenin sahip olması gereken en önemli sorumluluk ve yeterliklerden bazıları olarak kabul edilmektedir (Aydın, 2017). İlişki düzenlemeleri boyutu ise; en basit anlatımla, sınıf içinde uyulması gereken kurallar ile öğrenci-öğrenci ve öğrenci-öğretmen arasındaki etkileşim olarak tanımlanabilir (Başar, 2009). Kurallar, bir grup içindeki düzeni sağlayan yönergelerdir ve toplumsal hayatta çok önemli bir yer tutar. İnsanlar arası ilişkilerin büyük bölümü kurallar yoluyla düzenlenir. Dolayısıyla toplumun küçük bir örneklemi sayılabilecek sınıf ortamında düzenin sağlanması için kuralların hayati bir fonksiyonu vardır. Son olarak davranış düzenlemeleri boyutu, sınıf içi etkinliklerin, istendik kazanımları ortaya çıkarak nitelikte olmasını, sınıf ortamının olumlu davranışları destekleyecek şekilde oluşturulmasını, ortaya çıkması muhtemel problem davranışların önlenmesini ifade eder. Bu bağlamda düşünüldüğünde, olumlu öğrenci davranışlarının pekiştirilmesi, olumsuz davranışların söndürülmesi, problem davranışların ortadan kaldırılması için geliştirilen çözüm yolları bu boyuta örnek verilebilir.

Sınıf yönetimi ile ilgili araştırmalar incelendiğinde, (Akcan, 2018; Akgün, Yarar ve Dinçer, 2011; Akın ve Koçak, 2007; Çakmak, Kayabaşı ve Ercan, 2008; Çubukçu ve Girmen, 2008; Denizel-Güven ve Cevher, 2005) bu araştırmalarda genellikle öğretmen görüşlerine göre veya sınıf içi gözlemlere dayalı olarak veri toplandığı görülmektedir. Ancak görüşme ve sınıf içi gözlem yöntemlerinin çeşitli sınırlılıkları vardır. 
Örneğin; öğretmen, kendisini mükemmel göstermek adına yapmadıklarını yapmış veya yaptıklarını yapmamış olarak görüş bildirebilir. Öte yandan sınıf-içi gözlemlerde de izlendiğinin farkında olan öğretmen doğal davranmayabilir. Bu sınırlılıklardan dolayı, sınıf yönetimini konu alan bazı araştırmalarda farklı yöntemler kullanma ihtiyacı doğmuştur. Film araştırmalarının bu ihtiyacı karşılayan yöntemlerden biri olduğu düşünülmektedir.

Sinema filmleri, aktarmak istediği mesajı, kısa bir süre içinde görsel ve işitsel olarak yoğun bir şekilde izleyicisine iletebilme özelliğine sahiptir. Filmler iletilmek istenen bilgileri sadece yazılı veya sadece görsel metinlere göre çok daha kolay bir şekilde aktarabilir (Birkök, 2008). Filmler bunu başka hiçbir kaynağın yapamayacağı şekilde yapar (Metzger, 2010). Ayrıca filmler, rol alan oyuncuların sanatsal yeteneklerini sergiledikleri bir mekânı tasvir eder. Bu da karmaşık mesajların izleyiciye iletilmesi açısından filmlerin başarılı materyaller olarak düşünülmesine yardımcı olur. Bu bağlamda, oyuncuların sanatsal rolleri yardımıyla, filmlerdeki öğretmen imajlarının davranış modelleri (Akcan ve Polat, 2016) filmi izleyen öğretmenler tarafından benimsenmelerini sağlanabilir.

Filmler, ortaya çıktı̆̆ ilk zamanlar eğlence amacıyla kullanılmalarına rağmen, ilk zamanlardan bu yana kültürel değişim için bir araç haline geldiği gerçeği ile, popüler kültür unsurları arasında kendine sağlam bir yer edinmiştir. Popüler kültür, medya araçları vasıtasıyla birey veya toplulukları etki altına alabilen araçlar olarak kısaca tanımlanmakta (Yaylagül, 2004) ve internet, film, televizyon, moda, müzik vb. şeklinde çeşitlendirilmektedir (Özkan, Arslan ve Kara, 2014). Popüler kültür, özellikle de film dünyasına hareket duygusu sağlayan, tanıdıklarından ve tanımadıklarından öğrenme alanları yaratmaktadır. Gonzalez, Graziela, Gonzalez, Rozenfeld ve Aurelio'nun (2015) da belirttiği üzere, bireylerinin popüler kültüre derinlemesine daldığı gerçeğinden hareketle "Hayat boyu eğitim" felsefesini benimsemiş toplumlarda üretilmiş olan filmlerin eğitim olgusundan bağımsız hareket etmesi de düşünülemez.

Son zamanlarda, filmler toplumlar için öğrenmeyi de beraberinde getiren pedagojik bir konumda yer almaktadır. Çoğu film senaryosu, yapımcı ve yönetmenler tarafından "öğretme" endişesi ile filme dönüştürülmemesine rağmen, izleyicinin farkında olmadan izlediği filmden çok şey öğrendiği düşünülmektedir (Hooks, 2009). Öğretmen özelinde düşünüldüğünde, olumlu öğretmen imajının sergilendiği film sahnelerini izleyen ve bu mesleği yapan öğretmenlerin olumlu tutum geliştirdikleri söylenebilir (Kaşkaya, Ünlü, Akar ve Özturan-Sağırlı, 2011). Sadece tutumlar değil, birçok faktör açısından, filmlerdeki karakterlerin tasvirine dayalı olarak izleyiciye katkıda sunabilir (Gilbert, 2014). Ek olarak, filmler yoluyla eğitim kurumlarına ve ilgili toplumsal kesime dair pek çok şey ortaya konulabilir. Bu nedenle filmlerin eğitim ile ilgili konuları işlemesi, aynı şekilde eğitim araştırmalarının da filmler üstünde yoğunlaşması şaşırtıcı bir sonuç değildir.

Weber ve Mitchell (1995) filmlerde öğretmen ve öğretmenlik mesleğinin kalıp yargılarına (stereotip) ve imajına ilişkin bulgulara ulaşılabileceğini belirtmektedirler. Buradan hareketle filmlerin, öğretmenler ile ilgili zengin bilgiler içerdiği söylenebilir. Filmlerde izleyicilere sunulan öğretmen karakterlerinin sınıf içi davranışları, bir bakıma öğretici bilgiler sunmaktadır. Filmlerdeki öğretmenlerin, görev başındaki veya göreve hazırlanan öğretmen adaylarının davranışları üzerinde etkili olabileceği düşünülmektedir. Bu açıdan filmlerdeki öğretmen davranışlarının çok önemli ve araştırılmaya değer bir konu olduğu söylenebilir. Önemli olduğu düşünülen bu konunun daha iyi anlaşılabilmesi ve ilgili alanyazına katkı sağlaması umudu ile mevcut araştırmada, eğitim temalı filmlerde gösterilen öğretmen karakterlerinin sınıf yönetimi davranışları incelenmeye çalışılmıştır.

Film kültürünün yaygınlaşmasıyla beraber öğretmenlerin ve öğretmenlik mesleğinin filmlerde işlenmesi araştırmalara da konu olmuştur. Son yıllarda özellikle okul ve sınıf içi yaşamın filmlerde sıklıkla işlenmeye başlaması, eğitim araştırmacılarının da dikkatini bu yöne çekmiştir. Özellikle yurtdışında bu anlamda y1llardır süregelen araştırmalar mevcuttur (Buchanan ve Huczynski, 2004; Burbach ve Figgins, 1993; Dalton, 1995; Dalton, 2013; English ve Steffy, 1997; Epstein, Rosenberg ve Smith, 1991; Fennell, 2013; Gazetas, 1992; Gilbert, 2014; Glanz, 1997; Grobman, 2002; Grunder, 2016; Hauseman, 2010; Huczynski ve Buchanan, 2004; Jowett, Jarvie, ve Seeley-Fuller, 1997; Judge, 1995; Mauer, 1998; McCambridge, 2003; Nederhouser, 2010; 
Novello, 1994; Serey, 1992; Smith, 2003; Swift, 1974; Tan, 1999; Thomas, 1998; Townsend ve Ryan, 2012; Trier, 2001; Weber ve Mitchell, 2003; Wolfrom, 2010). Ayrıca çok az da olsa konuyla ilişkili benzer araştırmalar ulusal alanyazında da yer almaktadır (Akcan ve Polat, 2016; Efendioğlu, 2013; Oruç ve Sarıbudak, 2015; Polat ve Akcan, 2017). Bu araştırmalarda filmler; öğretmen imajı (Akcan ve Polat, 2016; Efendioğlu, 2013), çokkültürlülük (Polat ve Akcan, 2017) ve eğitim ortamları (Oruç ve Sarıbudak, 2015) konuları açısından incelenmiştir. Görüldüğü gibi, ulusal alanyazında eğitimi konu edinen filmlere yönelik yapılan araştırma sayısı yurtdışı araştırmalarına kıyasla oldukça azdır. Ek olarak ulusal ve uluslararası alanyazında filmleri sınıf yönetimi açısından inceleyen herhangi bir çalışmaya rastlanmaması bu çalışmanın önemini artırmaktadır. Bu araştırmanın alanyazındaki eksikliğin giderilmesine yardımcı olacağı öngörülmekte ve eğitim içerikli film araştırmalarının kapsamını genişleteceği umulmaktadır. Bununla birlikte sonraki araştırmalara kaynak olarak ilgili alanyazına katkıda bulunacağ düşünülmektedir.

\section{Araştırmanın Amacı}

Araştırmanın amacı, Millî Eğitim Bakanlığı'nın (MEB) Eylül 2018 dönemi mesleki çalışma programı kapsamında öğretmenlerin izlemesi için önerdiği filmlerin sınıf yönetimin boyutları açısından incelenmesidir. Bu genel amaç bağlamında aşağıdaki sorulara yanıt aranmıştır.

Eğitsel filmlerde sınıf yönetimin boyutlarından;

Fiziksel ortamın yönetimi nasıldır?

1. Öğretimin yönetimi nasıldır?

2. Zaman yönetimi nasıldır?

3. Sınıfta ilişki yönetimi nasıldır?

4. Öğrenci davranışlarının yönetimi nasıldır?

\section{Yöntem}

\section{Araştırmanın Deseni}

$\mathrm{Bu}$ araştırma, hacimli materyaller üzerinden keşfetme ve yoruma dayalı bir çalışmayı amaçladığı için nitel araştırma yaklaşımında desenlenmiştir. Nitel araştırma, farklı disiplin alanları arasında bütüncül bir bakış açısıyla, çalışmaya konu olan problemleri yorumlayıcı bir yaklaşımla derinlemesine incelemeyi amaç edinen bir yöntemdir (Altunışık, Coşkun, Bayraktaroğlu ve Yıldırım, 2010). Yıldırım ve Şimşek (2016) nitel araştırma yöntemini; araştırma konularının doğal ortamında, gözlem, görüşme, doküman incelemesi gibi veri toplama tekniklerinin yardımı ile irdelenmesi süreci olarak tanımlamıştır. Bu yöntemle desenlenmiş çalışmalarda araştırma problemleri hakkında derin bir kavrayışa ulaşma amacı vardır. Bu bakımdan araştırmacı, merak ettiği olguyu keşfetmeye çabalar, problemin ardında yatan gerçeklerin izini sürer (Karataş, 2015).

\section{Çalışma Materyali}

Araştırmanın çalışma materyalini eğitim konulu filmler oluşturmaktadır. Bu amaçla okul öncesi, ilköğretim ve ortaöğretim kurumlarında görevli yönetici ve öğretmenlerin genel kültür, özel alan eğitimi ve pedagojik formasyon alanlarında bilgi ve görgülerini arttırmak, yeni beceriler kazanmak, eğitim ve öğretimde karşılaşılan problemlere çözüm yolları bulmak, öğrencinin ve çevrenin ihtiyaçlarına göre plan ve programları hazırlamak ve uygulamak amacıyla yapacakları Eylül 2018 dönemi mesleki çalışma programı kapsamında MEB'in tüm öğretmenlere izlemelerini önerdiği toplam 50 film arasından, bu çalışmasının amacına uygun dört film, araştırmanın örneklemine dâhil edilmiştir (MEB, 2018). Araştırmada amaçlı örneklem yöntemlerinden ölçüt örnekleme tekniği tercih edilmiştir. Ölçüt örnekleme tekniğinde, araştırmacılar tarafından çalışmanın amacına uygun önceden belirlenen çeşitli ölçütler göz önünde bulundurularak, örnekleme alınacak materyalin bu ölçütler yoluyla incelenmesini içerir (Yıldırım ve Şimşek, 2016). Diğer bir ifade ile çalışmanın amacı ile uyumlu özelliklere sahip durumların araştırma örneklemi olarak seçilmesidir. Böylelikle araştırmacının çalışmasında incelemede bulunduğu benzer durumların aynı 
başlıklar altında toplanmasına yardımcı olur (Böke, 2014). Araştırmada MEB tarafından önerilen 50 film arasından sınıf içi uygulamaların en yoğun sahnelendiği dört film ölçüt örnekleme tekniği ile seçilmiştir. Ölçüt örnekleme yöntemi ile seçilen filmlere ilişkin bilgiler Tablo 1'de yer almaktadır.

Tablo 1. Örnekleme Alınan Filmler

\begin{tabular}{llccc}
\hline & Filmin adı & Yönetmen & Senarist & Y1lı \\
\hline $\mathbf{1}$ & Ölü Ozanlar Derneği (Dead Poets Society) & Peter Weir & Tom Schulman & 1989 \\
$\mathbf{2}$ & İki Dil Bir Bavul & Orhan Eskiköy, Özgür Doğan & Orhan Eskiköy & 2008 \\
$\mathbf{3}$ & Sinıf (Entre Les Murs) & Laurent Cantet & Laurent Cantet, François Bégaudeau & 2008 \\
$\mathbf{4}$ & Bay Lazhar (Monsieur Lazhar) & Philippe Falardeau & Philippe Falardeau, Evelyne de la Chenelière & 2011 \\
\hline
\end{tabular}

Tablo 1'e göre, araştırma kapsamına alınan filmlerin 1989 ile 2011 yılları arasında yayımlandığı görülmektedir. Örnekleme alınan filmlerden biri ABD (Ölü Ozanlar Derneği), biri Türkiye (İki Dil Bir Bavul), biri Fransa (Sınıf) ve diğeri Kanada (Bay Lazhar) yapımıdır.

\section{Verilerin Toplanması}

Nitel araştırmalarda veri toplama işlemi, gözlem ve görüşme tekniği ile yapılabileceği gibi doküman inceleme tekniği ile de yapılabilir. Bu araştırmada da verileri toplamak için doküman incelemesi tekniği uygun görülmüştür. Araştırmanın üzerinde odaklandığı konunun özelliğine göre gözlem ve görüşme yapmanın mümkün olmadığı durumlarda doküman inceleme yoluyla veriler toplanabilir. Doküman incelemesi, incelenmesi amaçlanan olay veya olgular hakkında derin bilgiler içeren yazılı, basılı, görsel ve/veya işitsel materyallerin incelenmesini ifade eder (Yıldırım ve Şimşek (2016). Hill'e (1993) göre, dokümanlar araştırmacılar için nitel araştırmalarda etkili bir şekilde kullanılabilecek zengin ve önemli bilgi kaynaklarıdır.

Çalışmada araştırmacılar tarafından geliştirilen film analiz formları veri toplama aracı olarak kullanılmıştır. Film analiz formları geliştirilirken, sınıf yönetiminin beş alt boyutu temel alınmış, daha sonra ayrıntılı veri setleri elde edilmesi için her bir boyuta ilişkin alt boyutlar belirlenmiştir. Ardından bu boyut ve alt boyutların film sahnelerinde ilişkili oldukları bölümler betimsel olarak ifade edilmiştir. Örneğin, Sınıf yönetiminin ilişki yönetimi boyutu için, kuralların oluşturulması, nazik konuşmak, öğrencilere isim ile hitap etme, beden dilini etkin kullanma, dönüt verme gibi alt boyutlara ayrılarak film sahnelerinde bu alt boyutlarla ilişkili durumlar tespit edilmeye çalışılmıştır. Veri toplama araçlarının geçerliliğini arttırabilmek için film analizi çalışmalarında bulunan iki uzmanın görüşleri alınmış, bu görüşler doğrultusunda birkaç değişiklik yapılarak formlara son hali verilmiştir. Bu aşamadan sonra her bir araştırmacı, geliştirilen bu formları, araştırma örnekleminde olmayan iki ayrı film üzerinde denemiş ve formların araştırmada kullanılabileceği kanaatine varmıştır. Araştırma sürecinde, örnekleme dahil edilen her bir film, iki araştırmacı tarafından ayrı zaman ve mekanlarda sahne sahne incelenmiş ve kayıt altına alınmıştır.

\section{Verilerin Çözümlenmesi}

Araştırmada elde edilen verilerin çözümlenmesinde betimsel analiz tekniği kullanılmıştır. Betimsel analiz, toplanan verinin önceden belirlenmiş olan temalara göre özetlenmesi ve yorumlanmasına dayanan bir nitel veri analiz türüdür (Özdemir, 2018). Betimsel analiz tekniğinde, araştırmacının tespit ettiği noktaların, çarpıcı bir şekilde sunulması amacıyla doğrudan alıntılara sıklıkla yer verilmesi esastır. Bu teknikte temel amaç, elde edilen bulgular hakkında, okuyucuya sade ve yorumlanmış bir şekilde bilgi vermektir. Betimsel analiz temelde dört adımda gerçekleşir. İlk aşamada, araştırmacı çalışmanın ana çerçevesini oluşturacak temaları belirler. Ardından araştırmada elde ettiği verileri, belirlediği bu temalara göre inceler. Üçüncü aşamada, incelediği verileri tanımlar, gerekli yerlerde kanıtlar sunar, doğrudan alıntılar yapar. Son aşamada ise bulguları ilişkilendirir, bulgular arasındaki bu ilişkileri açıklar, yorumlar, farklı olgular arasında karşılaştırma yapar. Bu şekilde karmaşık ve yüzeysel görünen olay ve olguları okuyucunun anlayacağı bir şekilde açıklamış olur (Yıldırım ve Şimşek, 2016).

Verilerin analizi sürecinde kayıt altına alınan film analiz formları deşifre edilip çözümlemeler yapılmıştır. Birinci aşamada önceden belirlenmiş temalar ile sınıf yönetiminin boyutları genel hatlarıyla 
ortaya konulmuştur. Daha sonra filmlerin ayrıntılı izlenmesiyle, her bir boyuta ilişkin daha ayrıntılı veriler elde edilip kayıt altına alınmıştır. Ardından kayıt altına alınan veriler düzenlenmiş, hangi verinin hangi boyut veya alt boyuta ait olduğu betimsel olarak ifade edilmiştir. Son olarak filmlerdeki öğretmen davranışlarının betimsel ifadeleri, film kareleri ve doğrudan alıntılar ile desteklenmiştir. Örneğin, sınıf yönetiminin fiziksel düzen boyutuna ilişkin öğrenci sıra ve oturma düzeni ele alındığında, tek sırada dört öğrencinin oturtulması, sınıf yönetimini güçleştireceği şeklinde değerlendirilmiş ve bunun olumsuz bir alg1 yaratacağı düşünülmüştür.

\section{Araştırmanın Geçerliği ve Güvenirliği}

Araştırmanın geçerliğini sağlamak ve artırmak için; araştırmanın ilk adımından son aşamasına kadar olan tüm süreç ayrıntılı bir şekilde açıklanmıştır. Ayrıca elde edilen bulgular film kareleri ve doğrudan alıntılar ile birlikte verilmiş, literatürdeki diğer çalışmalar ile karşılaştırılarak gerekçeleriyle desteklenmiştir. Benzer şekilde araştırmanın güvenirliği için, filmlerin analiz sürecinde her iki araştırmacı filmleri farklı zaman ve mekanlarda inceleyerek, elde ettikleri bulguları zaman kaybetmeden gözlem formları yardımıyla kayıt altına almıştır. Ardından iki araştırmacı aynı filmi beraber inceleyerek kayıt altına aldıkları sonuçları karşılaştırmış, benzer bulgular olduğu gibi değerlendirilmiş, farklı bulgular ise üzerinde tartışılarak uzlaşıya varılmıştır. Bu şekilde uyuşum yüzdesi de hesaplanmıştır. Uyuşum yüzdesi, gözlenen sınıf yönetimi davranışları ile görüş birliğine varılan sonuçların oranlaması yoluyla hesaplanmıştır. Elde edilen uyuşum yüzdesinin güvenilir bir oranda olduğu kanaatine varılmıştır $(>\% 80)$. Çok nadir de olsa, her iki araştırmacının üzerinde uzlaşamadığı gözlem sonuçları için uzman görüşüne başvurulmuş ve görüş birliğine varılmıştır.

\section{Bulgular}

Sınıf ortamındaki 1sı, 1şık, gürültü düzeyi, temizlik, duvar süslemeleri, eşya düzenlemeleri, sınıf mevcudu, sınıfın tüm öğrencilere uygunluğu gibi değişkenler sınıfın fiziksel öğeleri olarak sayılabilir. Bu fiziksel değişkenlerin motive edici, eğitici ve ilgi uyandırıcı bir şekilde düzenlenmesi etkili bir sınıf yönetiminin öncülleri arasındadır. Araştırma kapsamında yer alan filmlerde sınıf yönetiminin fiziksel düzenleme boyutuna ilişkin bulgular incelendiğinde genel olarak sınıf yönetimine olumlu katkı sağlayacak şekilde planlandığı görülmektedir.

Ölü Ozanlar Derneği filminde sınıfta öğrenciler birer kişilik sıralarda oturmaktadır. Sınıf tahtası ve sınıf kitaplığı öğrencilerin arka kısmındadır. Sınıfta yeteri kadar kitaplık ve kitap olduğu görülmektedir. Aynı zamanda öğrencilerin oturduğu sıraların arkasında da bir adet sınıf tahtası vardır. Sınıfta iki adet kapı bulunmaktadır. Öğretmen masası öğrencilerin karşısında ortalı şekildedir. Sınıf temizlik, ş̧ık, öğrenci sayısı, oturma düzeni gibi konular açısından ideal görünmektedir. Aynı zamanda sınıfta öğretmenlerin kullanabilmesi için küçük bir oda (bölme) olduğu da görülmektedir.

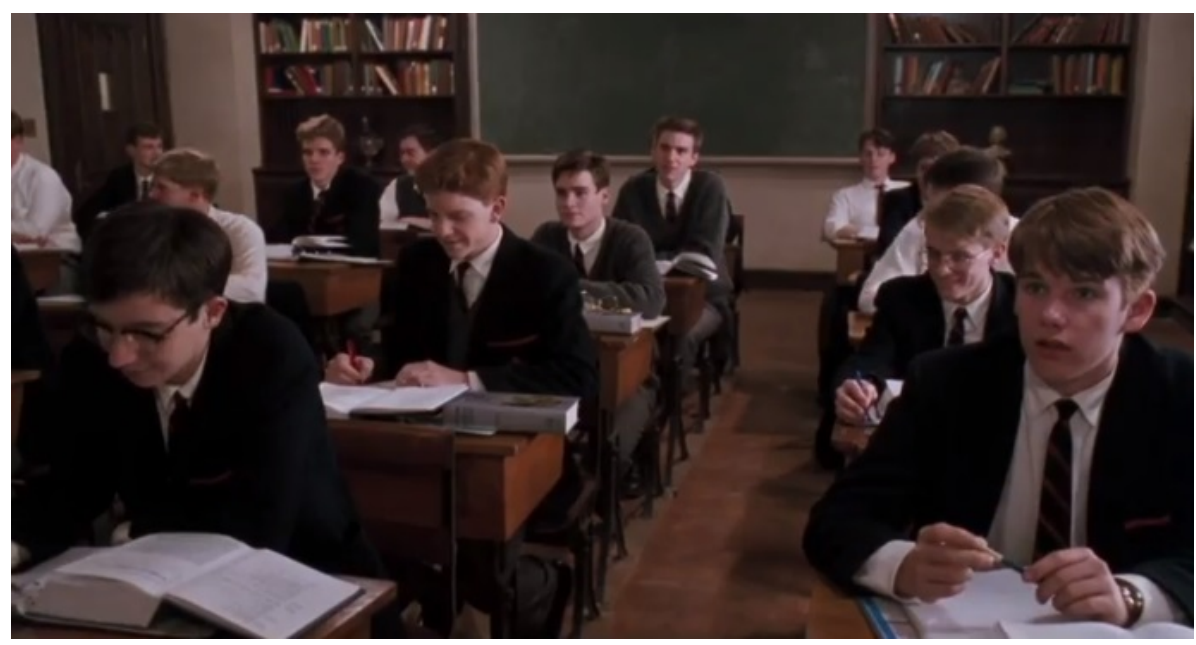

Görsel 1. Ölü Ozanlar Derneği filminde fiziksel düzene ait bir kare 
Sınıf adlı filmde; sıraların düzenli, ses düzeyinin uygun, 1ş1k seviyesinin iyi ve oturma düzeninin eğitim-öğretim etkinliklerine ve kullanılan öğretim yöntemine uygun olduğu söylenebilir (Görsel 2). Öğrencilerin tekli sıralarda oturması dikkat çekmektedir. Tekli sıralarda oturma düzeni araştırma örneklemindeki bir diğer film olan "Ölü Ozanlar Derneği" adlı filmde de görülmektedir (Görsel 1). Ancak incelenen "İki Dil Bir Bavul" adlı filmde üç, hatta dört öğrencinin tek sırada oturduğu görülmektedir (Görsel 3). Hareket özgürlüğü konusunda tekli veya en fazla ikili şekilde düzenlenen sınıf oturma düzeninin ideal olduğu söylenebilir.

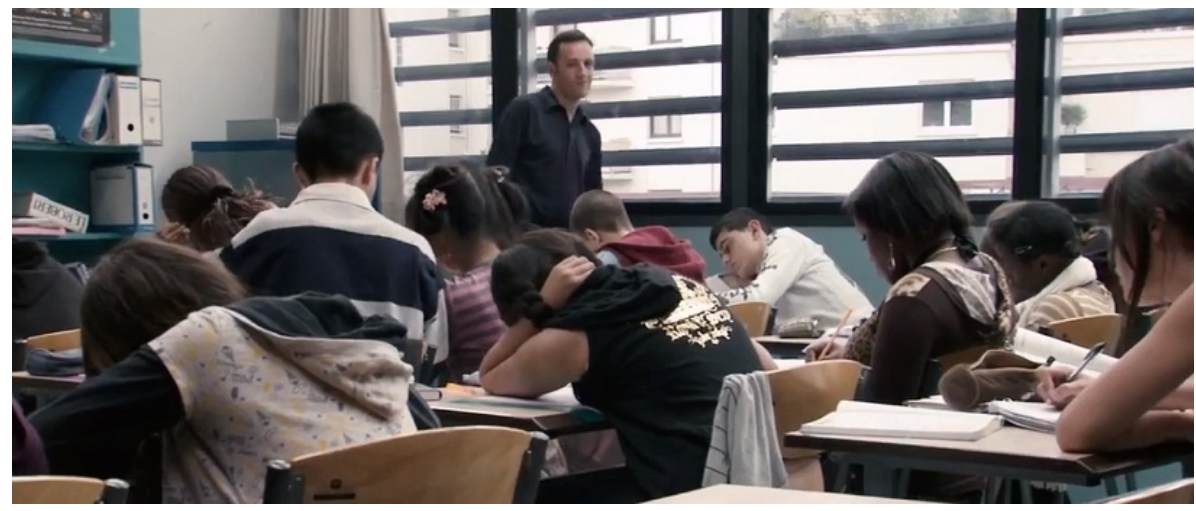

Görsel 2. Sınıf adlı filminde fiziksel düzene ait bir kare

İki dil bir bavul filminde yer alan alttaki karede, öğrencilerin aynı sırada 4 kişi oturdukları görülmektedir. Sınıf yönetiminin fiziksel düzenlemeler boyutunun önemli bir unsuru da sinıf mevcududur. Bununla birlikte sınıftaki sıraların öğrenci sayıları ile uyumlu olması gerekmektedir. Aksi takdirde gerek davranışsal gerekse de öğretimsel olarak hedeflenen kazanımlara ulaşılmasının oldukça güçleşebileceği öngörülebilir. Bu da sınıf yönetimini doğrudan etkileyebilecek olumsuz bir durumu işaret etmektedir.

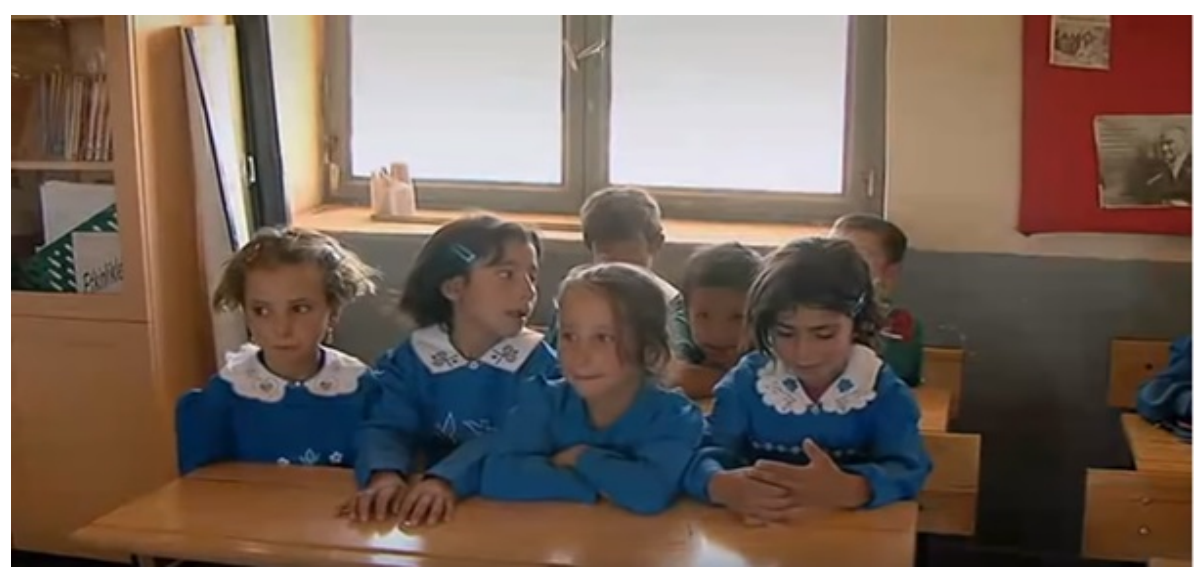

Görsel 3. İki Dil Bir Bavul adlı filminde fiziksel düzene ait bir kare

Bay Lazhar adlı filmde yer alan alttaki karede, bir önceki öğretmen olan Bayan Martine, grup çalışmasını verimli hale getirmek için, yani hedeflenen davranışlara ulaşabilmek için sınıf sıralarını yarım daire şeklinde kullanmıştır. Ancak kendisinden sonra gelen öğretmen Bay Lazhar ise geleneksel sıra düzenini kullanmak istemiştir. Burada dikkat edilmesi gereken nokta ise Bayan Martine, sıra düzeninin nedenini öğrencilerine anlatmışken, Bay Lazhar hiçbir gerekçe göstermeden öğrencilerini geleneksel düzene geçmeye zorlamıştır.

-Sıralar bilhassa mı böyle yarım daire yapıldı, söyler misiniz?

-Martine grup çalışmasını verimli hale getirmek için yapmıştı. Ekip ruhu için.

-Hımm... Siralarını tek sira haline getirelim.

-Hayır, hayır...

-Evet, evet, haydi haydi başlıyoruz. Yavaş yavaş... 

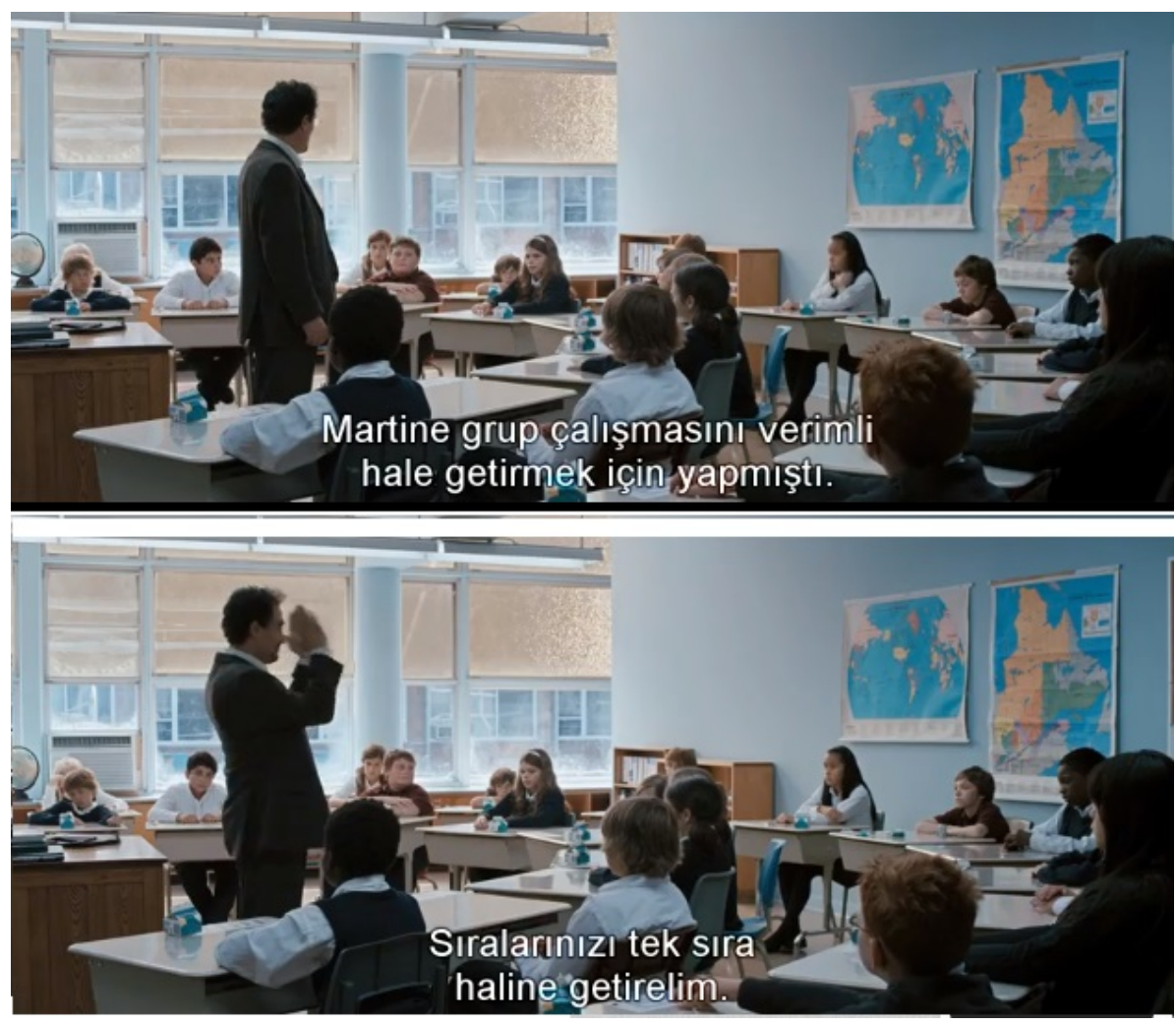

Görsel 4. Bay Lazhar adlı filminde fiziksel düzene ait bir kare

Öğretimin yönetilmesi, amaçlanan davranış örüntülerinin ve bu amaçlara ulaşmada kullanılacak olan materyallerin belirlenmesi, ders etkinliklerinin uygulanması, dönüt, değerlendirme, düzeltme, pekiştirme, güdüleme gibi etkinliklerin bütünüdür (Sadık, 2002). Bazı araştırmacılara göre sınıf yönetimi ve öğretim becerileri, öğretmen-öğrenci ilişkisinde önemli yer tutan iki uzmanlık alanıdır, çünkü derste sergileyeceği iyi bir yönetim ve öğretim performansı, öğrencilerde yüksek derecede olumlu imaj yaratır (Gilberts ve Lignugaris-Kraft, 1997; Underwood, 1987, aktaran. İlgar, 2007).

Ölü Ozanlar Derneği filminde, öğretmen derse giriş yaparken sınıfa ıslık çalarak girer, hiçbir şey söylemeden arka kapıdan çıkar ve öğrencileri sınıf dışına çekerek ders etkinliklerini başka bir ortamda, daha önceden planladığı gibi sürdürür. Dikkat çekme, özellikle öğrencilerin derse ilgisini toplama açısından oldukça önemli bir öğretimsel düzenlemedir. Ayrıca öğretmenin derse planlı bir şekilde geldiği anlaşılmaktadır.

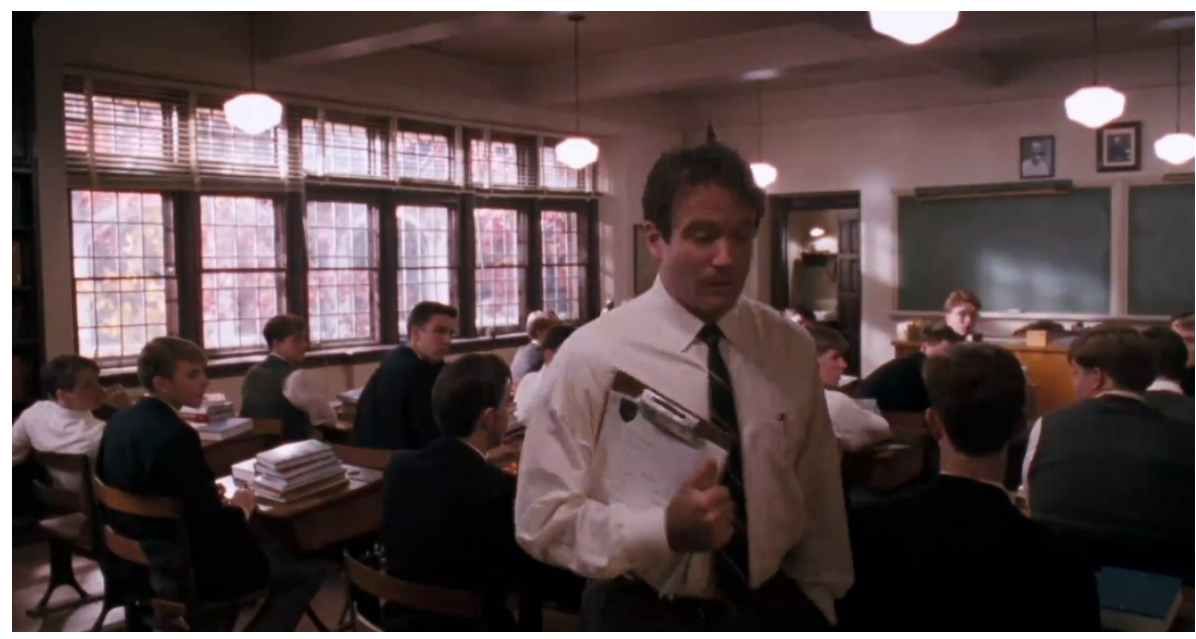

Görsel 5. Ölü Ozanlar Derneği adlı filminde öğretimsel düzenlemeye ait bir kare 
Sınıf adlı filmde öğretmenin yöntem olarak sadece anlatım tekniğini seçmesi öğrencilerin derse odaklanmasını zorlaştırmakta, dolayısıyla öğrenciler sınıfta uyumakta veya başka şeylerle meşgul olmaktadır.
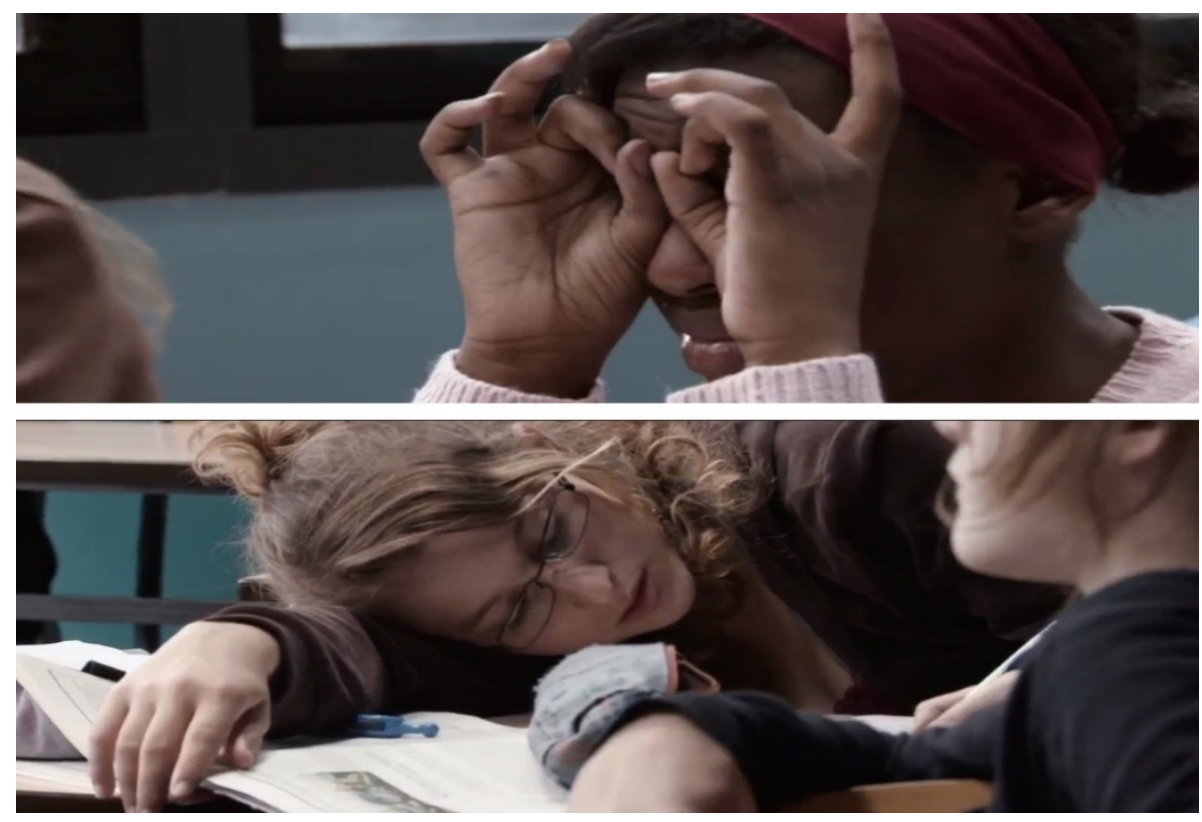

Görsel 6. Sınıf adlı filminde öğretimsel düzenlemeye ait bir kare

İki Dil Bir Bavul adlı filmde öğretmenin ilk okuma ve yazma öğretiminde kullanacağı kaynakları belirlediği ve sınıf ortamına getirdiği, dersi sadece anlatım yöntemi ile değil çeşitli materyaller ile sürdürdüğü görülmektedir.

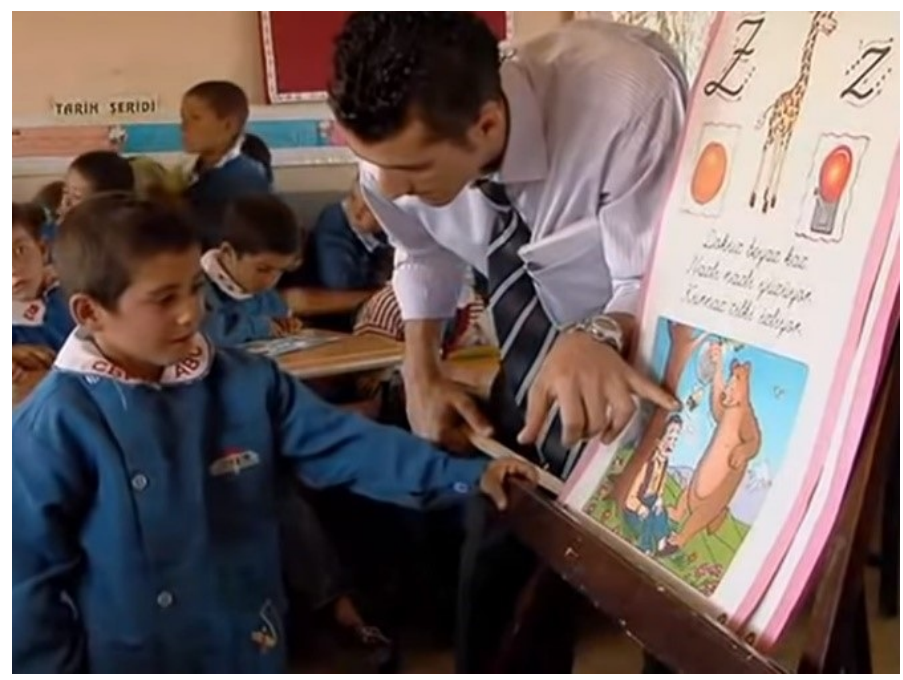

Görsel 7. İki Dil Bir Bavul adlı filminde öğretimsel düzenlemeye ait bir kare

Bay Lazhar adlı filmde öğretmen, ilkokul öğrencilerine Balzac'tan bir metin kullanarak dikte çalışması yaptırmış, ancak sonuçtan hiç memnun kalmadığını belirtmiştir. Öğretmenin bu sözlerine karşılık öğrenciler, metnin kendilerine uygun olmadığına dair söylemlerde bulunmuştur.

-Şimdi, seviyenizi belirleyebilmem için küçük bir yazım sınavı yapalım.

-Okuduğunuzdan mı?

-Hadi kalemleri çıkarın.

Sınavdan sonra değerlendirmede bulunan öğretmene öğrencinin verdiği tepki dikkat çekicidir.

-(Öğretmen) Tebrik edecek bişeyim yok. 
-(Öğrenci) Tabi, bu Çinli Fransızcasıydı. (Gülüşmeler).

Aynı bulgu başka bir sahnede özne-belirteç öbeği anlaşmazlığında görülmektedir.

-Özneyi bulmak için soruyoruz. Kim ya da ne yeterli gelmeliydi.

-O bir belirleyici.

$-\mathrm{Ne}$ ?

-Niteleyici.

- (Öğretmen kısa bir şaşkınlıktan sonra devam eder). Evet, özneyi bulmak için kim sorusunu soruyoruz. Kim yeterli gelmeliydi? Benim bin yüz Frangım. Frang özne. Benim, şahıs zamiri.

-O bir belirleyici. İyelik zamiri var. Artık şahıs zamirleri olmadığını herkes bilir.

- (Diğer öğrenci) Annem halen olduğunu söylüyor.

- (Öğretmen) Annenle benim dil bilgimiz aynı.

Aynı zamanda öğretmenin öğrencilerin seviyesine inemediğini Krizalit kelimesini sınıfta anlatmasıyla görmekteyiz.

-Aranızdan bir kişi krizaliti doğru yazmış. Herhalde o da kazayla oldu...Krizalit nedir?

- Bir çiçek.

- Krizantemle karıştırdın herhalde. Başka yok mu? Krizalit tırtılla kelebek arasında bir böcektir. Hassas bir ipek kozasında yakında kanatlarını açmaya hazırdır. Sizin gibi.

- Balzac gibi konuşuyorsunuz!

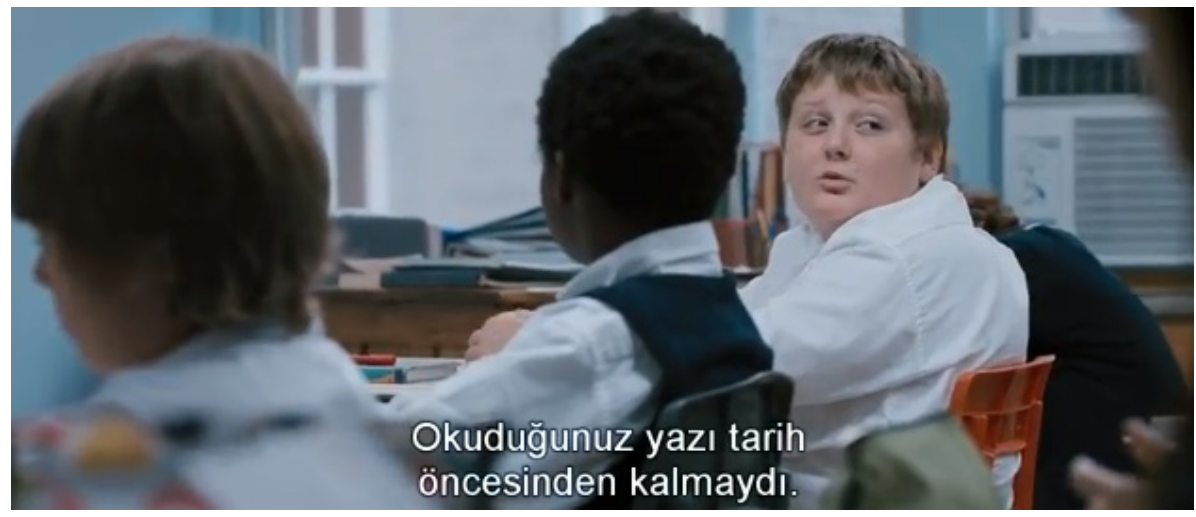

Görsel 8. Bay Lazhar adlı filminde öğretimsel düzenlemeye ait bir kare

Öğretmen, sınıfta zamanı yönetmek açısından başarılı olmak zorundadır. Çünkü hedeflenen amaçlara ulaşabilmesi için daha önceden sınırlanmış 1 (bir) ders saati vardır. Bu kısıtlı zaman diliminde amacına ulaşabilirse etkili bir öğretim gerçekleştirdiği söylenebilir. Üstün, Nural ve Değer (2005) öğretmenin sınırları önceden belirlenmiş olan bu zaman dilimini etkili kullanabilmesi için derse nasıl başlayacağını, derste hangi öğretim yöntem ve teknikleri kullanabileceğini, hangi materyali ne zaman değerlendireceğini, konunun hangi bölümünde hangi sorularla öğrencileri nasıl yönlendireceğini ve zamanın sonuna doğru öğrencilere dönüt, düzeltme ve değerlendirme işlemlerini nasıl yapacağını planlaması gerektiğini belirtmektedir.

Ölü Ozanlar Derneği filminde öğretmen öğrencilerine vermek istediği mesajı çok ilginç bir şekilde sunmaktadır. Kitabın giriş kısmından bir paragraf okutarak kendisi de cümleleri tahtaya geçirmeye çalışmakta, ancak bu fikre hiç katılmadığını, hatta kitabın giriş kısmının tamamen yırtılıp uzaklaştırılması gerektiğini söyler ve öğrencilerden de bunu ister.

-Şimdi o sayfayı yırtmanızı istiyorum. Sayfayı tamamıla yırtın! Beni duydunuz, yırtsanıza! Yırtsanıza! Haydi, yırtın. Teşekkürler Bay Dalton. Sadece o sayfayı değil, bütün giriş bölümünü yırtın. Hepsi gitsin, hiçbir iz kalmasın. Yırtın onu, yırtın.... Bu kutsal bir kitap değil, cehenneme gitmezsiniz. Temiz bir şekilde yırtın, hiçbir şey kalmasın...

Daha sonra öğrencileri etrafına toplayarak asıl vermek istediği mesajı, yani hedeflediği kazanımı verir. Öğretmenin bu hareketi onun derse hazırlık yaptığını ve belli bir planlama ile derse geldiğini göstermektedir. Bu davranış zamanı etkin kullanabilmesi açısından öğretmene avantaj sağlayan bir hareket olarak değerlendirilebilir. 


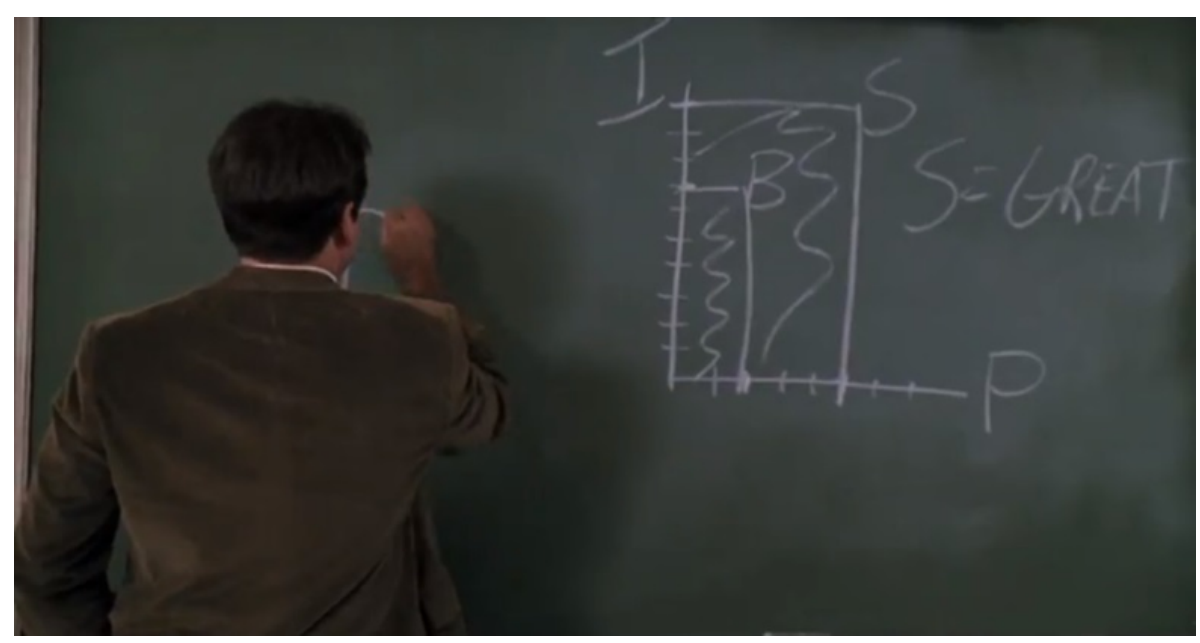

Görsel 9. Ölü Ozanlar Derneği adlı filminde zaman yönetimine ilişkin bir kare

İki Dil Bir Bavul adlı filmde öğretmenin bir öğrenci ile ilgilenirken, diğer öğrencilerden bir kısmının ayakta dolaştığı, kendi aralarında konuştuğu ve bir kısmının da çöp kutusu, kapı vs. gibi ders dışı unsurlar ile ilgilendikleri görülmektedir. Bire bir eğitim yapan öğretmenin, diğer öğrencilerin dersten kopmasını engellemek ve zamanı etkili kullanabilmek açısından ders öncesinde iyi bir planlama ve hazırlık yapmadığı anlaşılmaktadır.
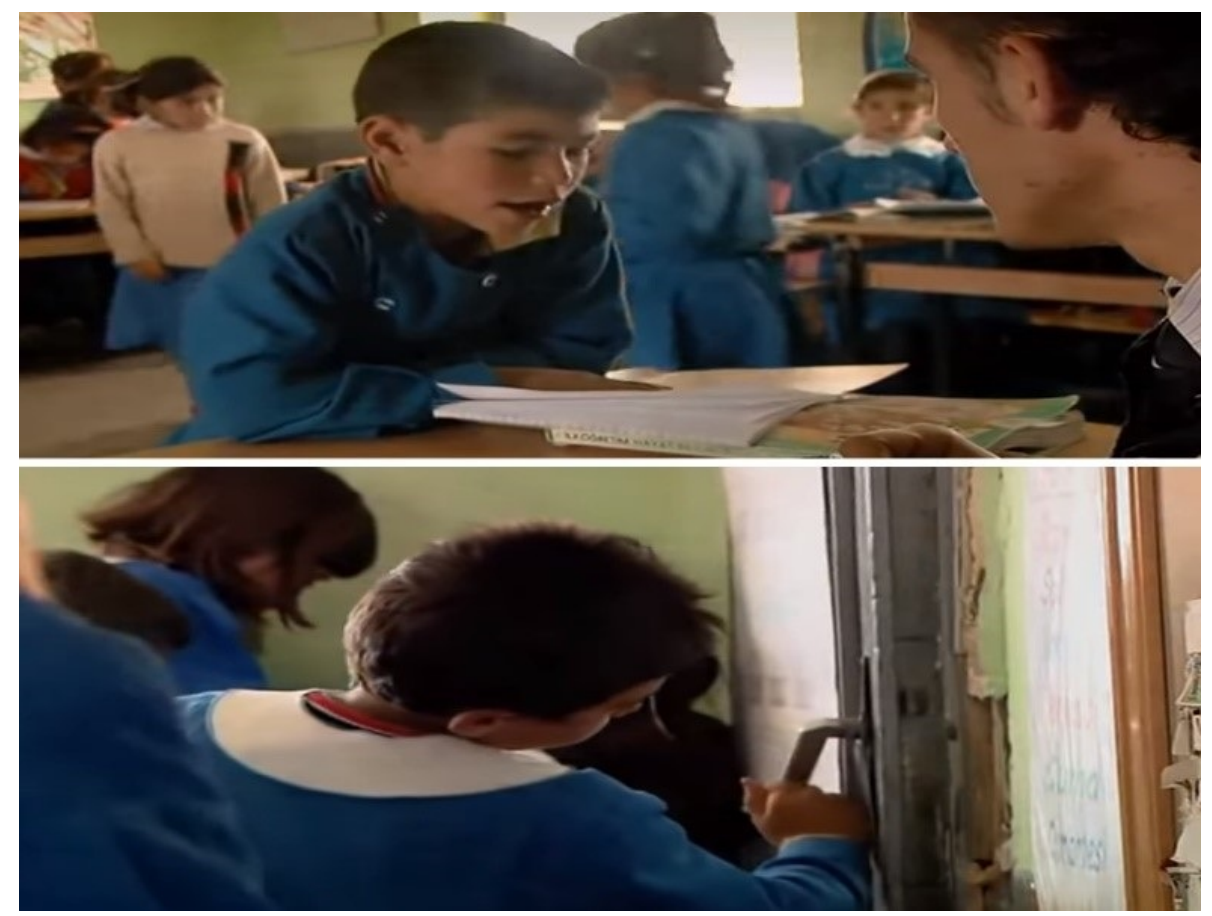

Görsel 10. İki Dil Bir Bavul adlı filminde zaman yönetimine ilişkin bir kare

Sınıf adlı filmde öğretmen öğrencileri kapıda karşılamaktadır. Sınıf yönetiminde zamanı etkili ve verimli kullanabilme adına öğretmenin sınıfa zamanında gelmesi önemli görülmektedir. Aynı zamanda öğretmen, derse zamanında girme konusunda öğrencilerine rol model olmaktadır. 


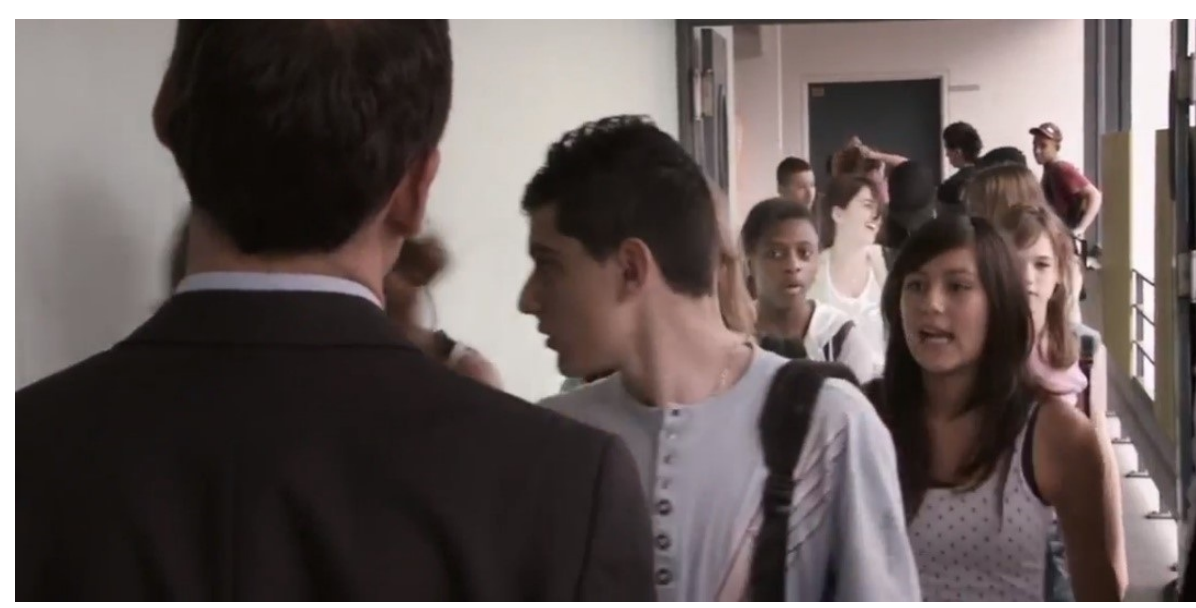

Görsel 11. Sınıf adlı filminde zaman yönetimine ilişkin bir kare

Bay Lazhar adlı filmde öğretmenin tahtayı ders zili çaldıktan birkaç dakika sonra sildiği ve aynı anda öğrencilerin de gürültü yaptıkları görülmektedir. Etkili bir zaman yönetimini engelleyen iki durumu aynı sahnede bir arada görülmektedir. Bu bağlamda öğretmenin tahtayı silme işini öğrencilerine ders başlamadan önce yaptırmasının zaman yönetimi açısından önemli olduğu değerlendirilmektedir.

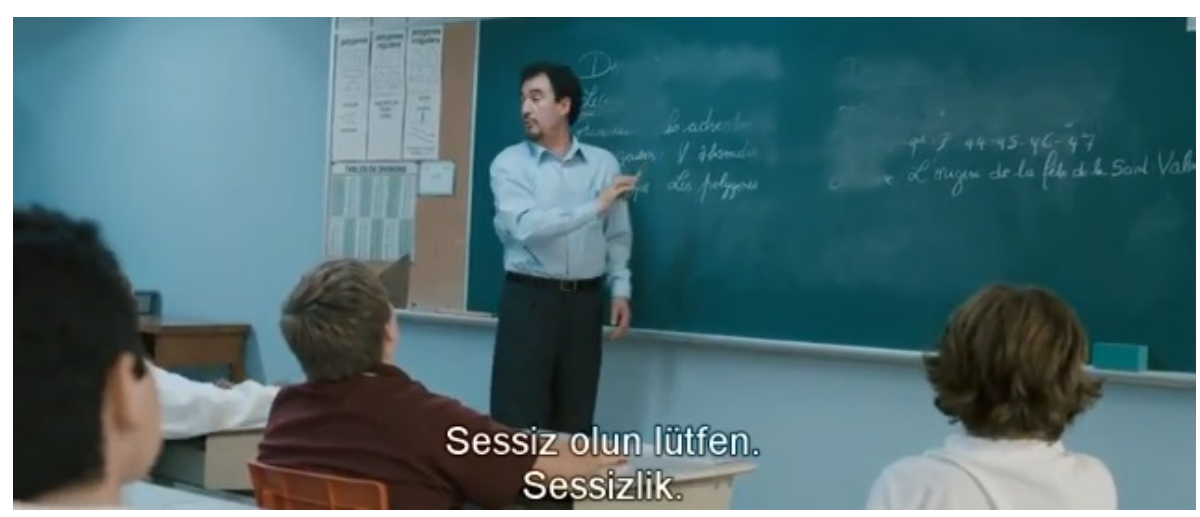

Görsel 12. Bay Lazhar adlı filminde zaman yönetimine ilişkin bir kare

İnsanlar sosyal varlıklardır ve bu sosyal hayatta uyum içinde yaşayabilmek için uyulması gereken bazı normlar bulunmaktadır. Sosyal normlar kısaca, belirli bir duruma uygun davranış örüntüleri ile ilgili toplumsal uzlaşma veya görüş birliğidir ve insanlar genellikle bu sosyal normların farkına varır varmaz uyum gösterme eğilimindedirler (Atkinson, Aktinson ve Hilgard, 1995). Sınıf ortamının, toplumun küçük bir kesimini temsil ettiği düşünüldüğünde, öğrencilerin uyması gereken sosyal norm veya kuralların öğrencilere benimsetilmesi, sınıftaki yaşamın belirli bir düzen içinde sağlıklı işlemesine yardımcı olur. Başar'a (2009) göre, uyulması gereken kurallar, öğretmen-öğrenci veya öğrenci-öğrenci arasındaki etkileşim, ilişki yönetimi boyutuna dâhil edilebilir. 


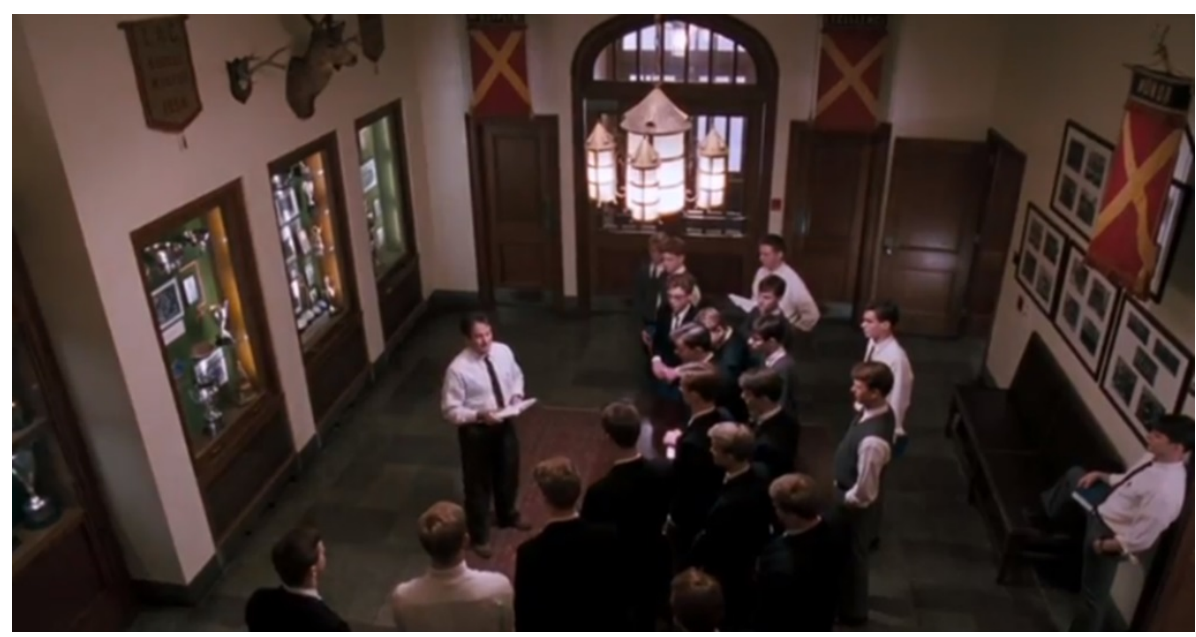

Görsel 13. Ölü Ozanlar Derneği adlı filminde ilişki yönetimine ilişkin bir kare

Sınıf adlı filmde öğretmen davranış sorunu olan birçok öğrencinin bulunduğu sınıfta oldukça sakin kalmaya ve öğrencileri anlamaya çalışmaktadır. Çoğu kişinin kızacağı durumlarda, davranışlarını kontrol ederek öğrencilerle 1 lımlı bir ilişki içinde olduğu görülmektedir. Öğrencilere, fikirlerini arkadaşlarına ve öğretmene sunma fırsatı vermektedir. Öğrenciler ile doğrudan ve basit bir şekilde konuşarak gerekli yerlerde dönüt düzeltme vermektedir. Tüm bunları yaparken belirli toplumsal normları göz önünde bulundurmaktadır.

-Haydi, söyle, söyle, söyle. (Öğrenci 1)

-Sus dedim sana, susacak misın? (Öğrenci 2)

-(öğretmen) Söyle bakalım.

-Eğer söylersem kendime Guantanamo' da yer ayırtmış olurum.

-Hayır, hayır.

-Benimle dalga geçecekler.

-Kimse seninle dalga geçmeyecek. Bir sorun mu var? Söyle.

-Ama çok kötü bir şey söyleyeceğim.

-Önemli değil. Söyle.

-Canınızı sıkabilir.

-Şunu artık söyler misin Süleyman?

-Kızmayacağınıza söz veriyor musunuz?

-Tamam ama acele et.

-Bakın, bunu başkasından duydum, tamam mı? Ben söylemedim, kulağıma geldi. Bazıları sizin erkeklerden hoşlandığınızı söylüyor. İnanın bana, herkes bunu konuşuyor. Ben söylemedim ama!.... doğru mu değil mi?

-Hayır, doğru değil, seni hayal kırıklığına uğrattığım için üzgünüm. Pekâlâ bu durum Süleyman'ın umurunda olmadığına ve takıntılarını hallettiğimize göre artık haber kipinin hikayesine geri dönebiliriz.

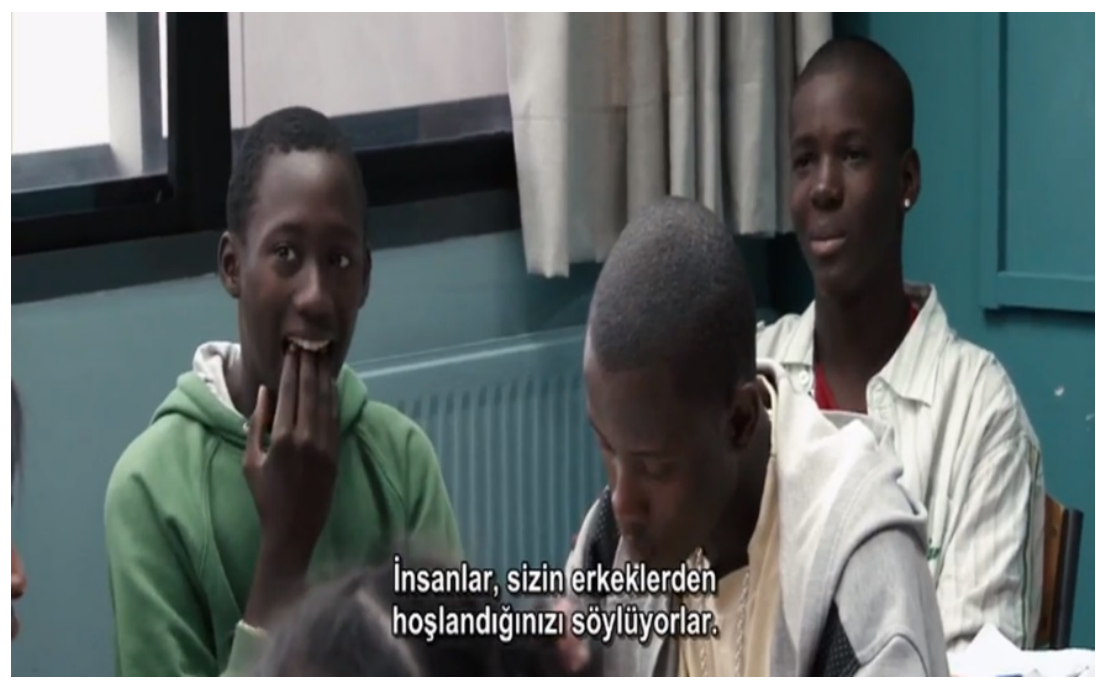

Görsel 14. Sınıf adlı filminde ilişki yönetimine ilişkin bir kare 
İki Dil Bir Bavul adlı filmde öğretmen ilk derste öğrencilerinin ve velilerin isimlerini (Görsel 15) öğrenip gerekli gördüğü notları aldıktan sonra sınıf kurallarını oluşturduğu görülmektedir. Sınıf kurallarını oluştururken "ben dili" kullanmakta, öğrencilerine açık ve anlaşılır talimatlar vermektedir. Dil sorunundan dolayı anlaşılmayan kısımları bizzat uygulayarak göstermektedir (Kalemi çöpte açtırması). Ayrıca öğretmenin önce sınıfta yapılacak etkinlikle ilgili yönergeyi açıkça verdiği ve daha sonra yapılması gereken etkinliği tahtaya yazdığı görülmektedir.

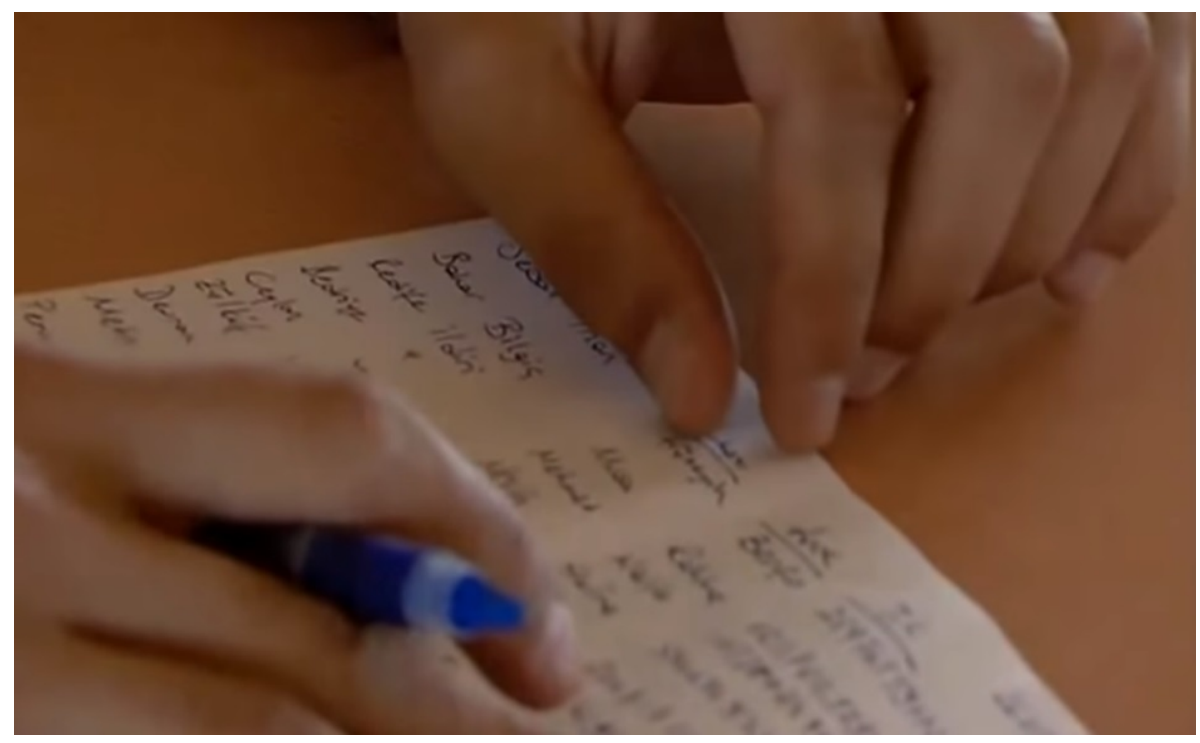

Görsel 15. İki Dil Bir Bavul adlı filminde ilişki yönetimine ilişkin bir kare

Bay Lazhar adlı filmde öğretmen, öğrencisinin derste fotoğraf makinesi ile kendisinin fotoğrafını çektiğini fark etmiştir. Öğretmen, bu davranış karşısında öğrenciye nezaket kuralları çerçevesinde öncelikle izin alması gerektiğini nazik bir dil ile belirtmiştir.

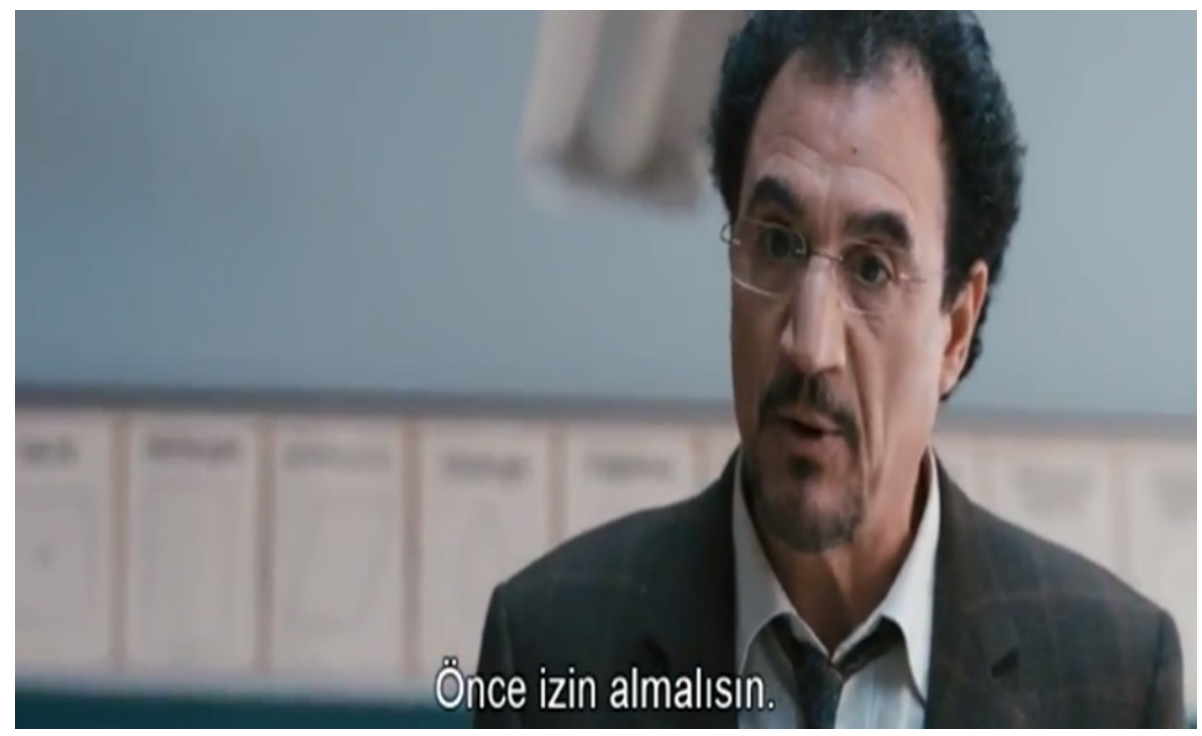

Görsel 16. Bay Lazhar adlı filminde ilişki yönetimine ilişkin bir kare

Davranış düzenlemesi boyutu, sınıfta yürütülecek olan etkinliklerin, istendik davranışları işler hale getirmesini ve sınıf atmosferinin olumlu davranışları destekleyecek şekilde oluşturulmasını içerir. Davranış düzenlemesi boyutuna, olası problem davranışların ortaya çıkmasının önlenmesi örnek olarak verilebilir. Buna ek olarak belirlenen kurallara uyulmasının sağlanması, problem davranışların istendik olanlarıyla değiştirilmesi, sınıfta öğrenilen olumlu davranış örüntülerinin farklı durumlara aktarılmasının sağlanması bu boyuta ilişkin örnekler olarak sıralanabilir (Başar, 2009). Bu bilgiler ışı̆̆ında öğretmenlerin problemli davranışlara yönelik geliştirdikleri çözüm yolları, davranış düzenlemeleri boyutunda değerlendirilebilir. 
Ölü Ozanlar Derneği filminde geçen bu sahnede (Görsel 17) öğretmen, verdiği ödevle adeta alay eden öğrencisine oldukça olumlu yaklaşarak olumsuz sonuçlanabilecek bir davranışı ortaya çıkmadan çözüme ulaştırmıştır.

-Kedi fareyi yedi.

-Kutlarım Bay Orkins.... Sana değil, sana doğru gülüyoruz. Basit temaların sakıncası yoktur, basit şeyler hakkında güzel şiirler yazılabilir, bir kedi, bir çiçek ya da yağmur... Şiir size hitap eden her konu hakkında olabilir, yeter ki yazdıklarınız sıradan olmasın.

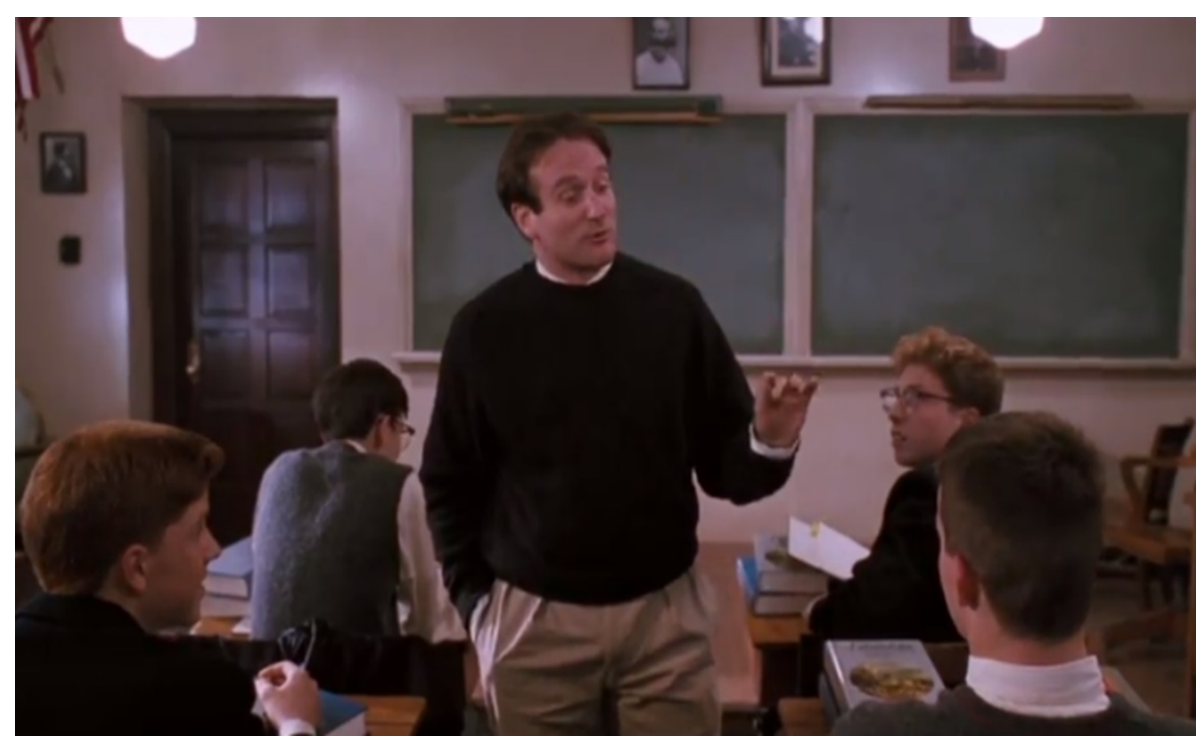

Görsel 17. Ölü Ozanlar Derneği adlı filminde davranış yönetimine ilişkin bir kare

Sınıf adlı filmde, filmin başından sonuna kadar öğrencilerin kurallara uygun hareket etmediği, öğretmenin de ideal olarak tanımlanabilecek bir sınıf ortamını oluşturmakta zorlandığını görmekteyiz. Özellikle bazı öğrencilerin yüksek düzeyde davranış bozukluğu gösterdiği, ancak öğretmenin bu konuda çok fazla müdahale etmediği görülmektedir.

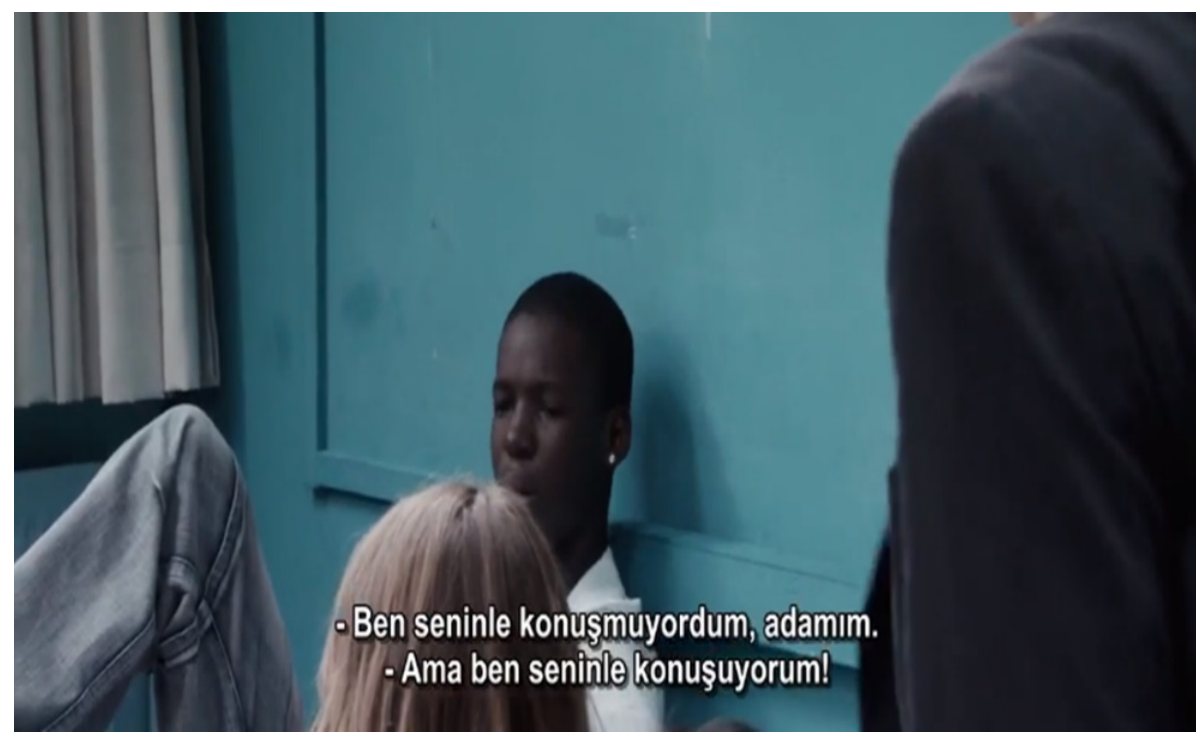

Görsel 18. Sınıf adlı filminde davranış yönetimine ilişkin bir kare

İki Dil Bir Bavul adlı filmde, öğretmenin öğrencilerine ceza verdiği görülmektedir. Bu bağlamda düşünüldüğünde öğretmen, problemli davranışı nedenleriyle birlikte değerlendirmek yerine doğrudan öğrenciyi cezalandırmayı tercih etmiştir. Ceza yöntemi, istenmeyen davranışın ortadan kaldırılması için olumlu davranışı ön plana çıkarmak yerine olumsuz davranışı daha da belirgin hale getirmektedir. 


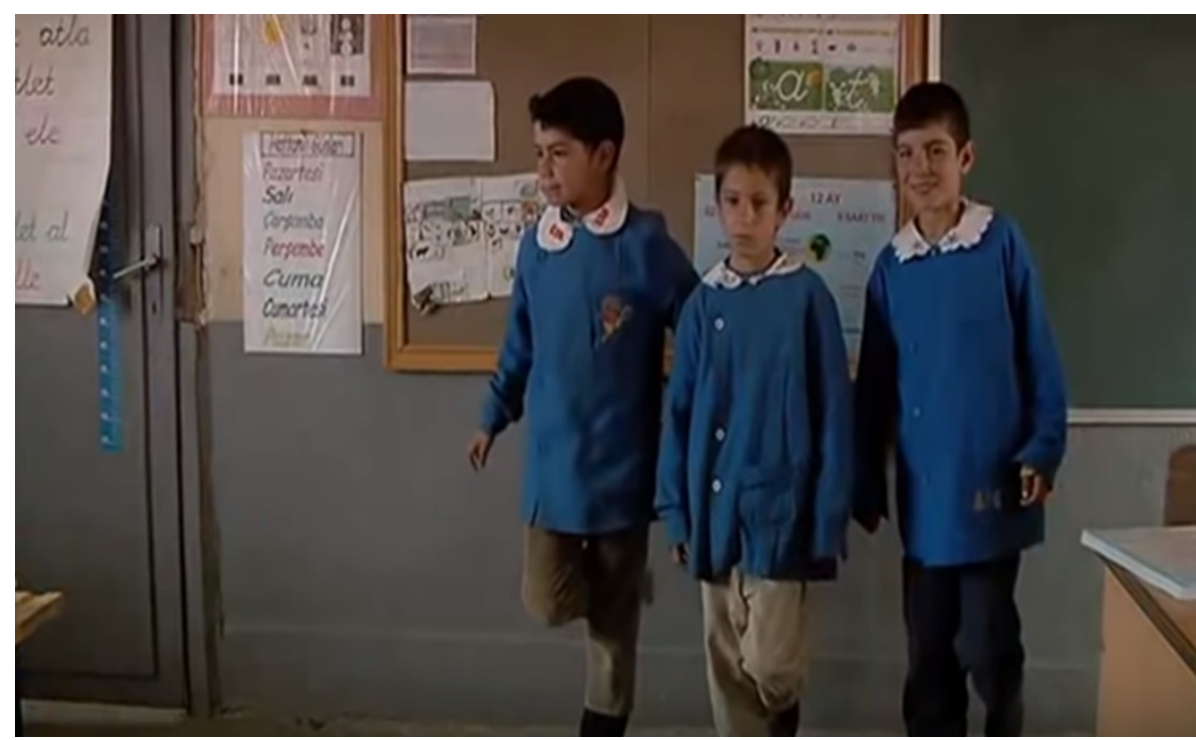

Görsel 19. İki Dil Bir Bavul adlı filminde davranış yönetimine ilişkin bir kare

Bay Lazhar adlı filmde, öğrencinin olumsuz bir davranışına karşılık olarak öğretmen öğrencinin kafasına tokat atarak olumsuz davranışa maruz kalan diğer öğrenciden özür dilemesini istemiştir.

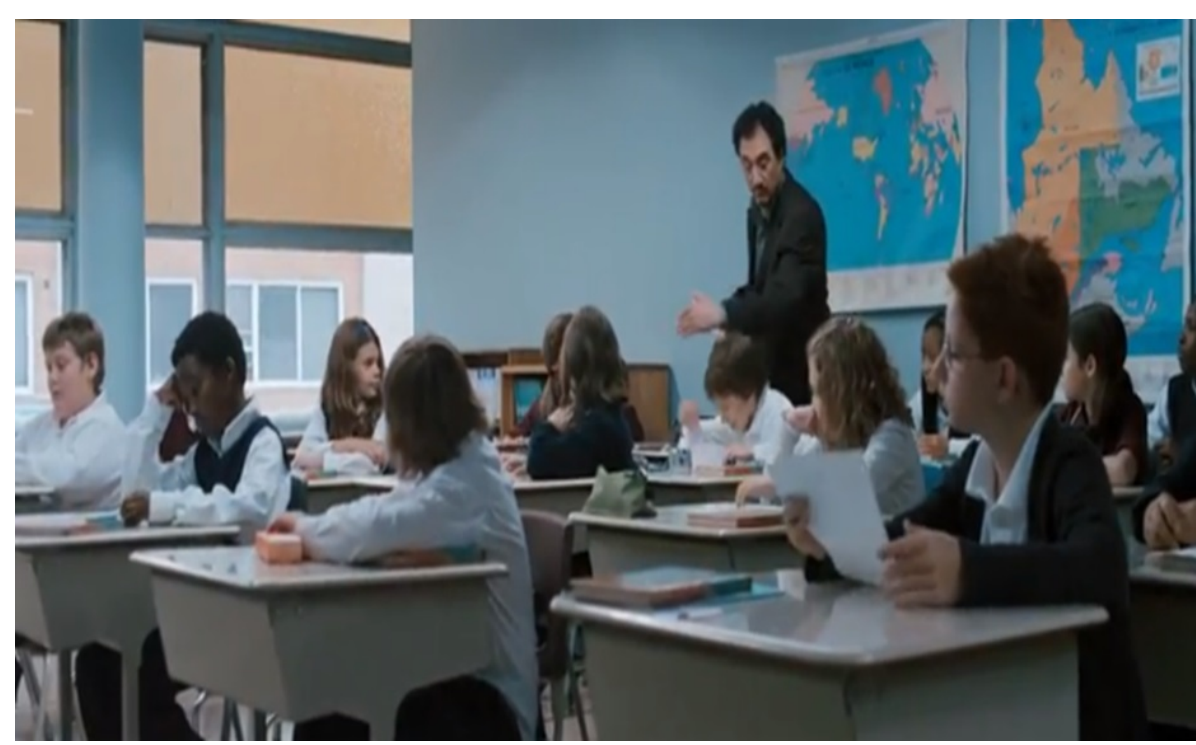

Görsel 20. Bay Lazhar adlı filminde davranış yönetimine ilişkin bir kare

\section{Sonuç ve Tartışma}

Bu araştırmada Millî Eğitim Bakanlığı'nın (MEB) Eylül 2018 dönemi mesleki çalışma programı kapsamında öğretmenlerin izlemesi için önerdiği filmlerin sınıf yönetiminin boyutları açısından incelenmesi amaçlanmıştır. Araştırmada ele alınan filmler sınıf yönetimin boyutları olan fiziksel düzen, öğretimsel düzenleme, zaman yönetimi, ilişkisel ve davranışsal düzenleme bağlamında incelenmiştir. İncelenen filmlerde sınıf yönetimi açısından olumlu ve olumsuz örnek teşkil edebilecek birçok davranışın olduğu ortaya çıkmıştır. Bunların içerisinden öğrencilerin tek kişilik sıralarda oturması, öğretmenlerin derse hazırlıklı ve öğrenciden önce gelmesi, öğrencilere ismi ile hitap etmesi ve sakin, samimi, nezaket kurallarına dikkat eden bir yapıda olmaları sınıf yönetimi açısından ön plana çıkan olumlu davranışlardır. Öte yandan öğretmen tarafından sınıfın seviyesine uygun olmayan bir metnin okutulması, dersin plansız bir şekilde işlenmesi ve tepkisel sınıf yönetimi modelinin benimsenerek ceza yöntemine başvurulması ise sınıf yönetimini olumsuz etkileyen davranışlar olarak belirlenmiştir. 
İncelenen filmler fiziksel düzen boyutu açısından değerlendirildiğinde, İki Dil Bir Bavul filmindeki sınıf ortamı dışında, diğer sınıf ortamlarının hedeflenen kazanımlara ulaşabilmeyi mümkün kılabilecek özellikte olduğu söylenebilir. Bu filmlerde öğrencilerin tek kişilik sıralarda oturduğu görülmektedir. Yıldırım’a (2019) göre, tek kişilik oturma düzenlerinde öğrencilerin bağımsız hareket ettiği ve tek kişilik sıraların sınıfta değişik biçimlerde düzenlenebildiği belirtilmektedir. Aynı zamanda yanlarında herhangi bir akranları oturmadığı için öğrencilerin dikkatinin dağıtılma ihtimali azalmaktadır (Garrett, 2014). İlkokul kademesindeki bir sınıfın konu alındığı İki Dil Bir Bavul filminde ise öğrenci mevcudunun fazla olmasından dolayı öğrenciler sıralara 3'er ve 4'er kişi oturmak zorunda kalmışlardır. Başar (2016), ilkokul kademesindeki öğrencilerin öğretmen desteğine diğer kademelerdeki öğrencilerden daha fazla ihtiyaç duyduğunu ifade etmiştir. Finn ve Achilles (1990) tarafından yapılan çalışmada da küçük (öğrenci sayısı az) sınıfların 1. sınıftaki öğrenci performansını olumlu yönde etkilediği belirlenmiştir. Bu nedenle, özellikle ilkokul kademesindeki sınıflarda öğrenci sayısının nispeten az olması, öğrencilerin daha fazla öğretmen desteği alması açısından doğru bir yaklaşımdır. Bu bağlamda İki Dil Bir Bavul filmindeki öğrenci mevcudunun sınıf yönetimini zorlaştırabileceği düşünülmektedir. Diğer yandan incelenen filmlerde sınıflardaki ışık düzeyinin fiziksel düzen açısından ideal olduğu söylenebilir. Işık (2020), sınıfın fiziksel düzenine ilişkin 1şıklandırmanın oldukça önemli olduğunu belirtmiştir. Yazara göre sinıflarda geniş ve sayıca fazla pencerenin bulunması gerekir. Sınıflarda yeterli ve doğal ışıklandırmanın olması öğrencilerin göz sağlı̆̆ının korunması ve etkili bir eğitim ortamının oluşturulması açısından önemli bir faktördür. Çünkü sınıftaki ışık miktarının az olması öğrencilerin motivasyonlarını düşürürken; fazla olması ise öğrencilerde stres ve sinirliliği artırabileceği için sınıfta istenmeyen öğrenci davranışlarının ortaya çıkmasına neden olabilir. Bu durumlar da sınıf yönetimini doğrudan olumsuz etkiler.

Sınıf yönetiminin diğer bir boyutu olan öğretimsel düzenleme açısından filmler değerlendirildiğinde, olumlu ve olumsuz etkilere neden olabilecek davranış ve uygulamaların olduğu görülmüştür. Ölü Ozanlar Derneği filmindeki öğretmenin derse hazırlıklı gelmesi ve dersin giriş kısmında öğrencilerin dikkatini çekmesi oldukça önemlidir. Öğretmenlerin ders öncesinde derse ilişkin hazırlık yapması, dersin akışı ve öğretmenin ders sürecine hâkim olması açısından büyük önem taşır. Bir öğretmenin derse hazırlıklı gelerek, dersin zamanını daha etkili bir biçimde kullanabileceği ve ders içerisinde oluşabilecek belirsizlikleri önceden önleyebileceği düşünülmektedir. Aynı zamanda öğretmenin sorumluluklarının farkında olarak derse hazırlıklı gelme konusunda öğrencilerine model olması, ilerleyen süreçlerde öğrencilerin özenli ve dikkatli olmalarına yardımcı olacaktır (Cangelosi, 2016). İki Dil Bir Bavul filmindeki sınıf öğretmenin de sınıfa okuma-yazma konusunda materyal getirmesi ders öncesi hazırlık yaptığını göstermektedir. Aynı zamanda sınıfta öğretim teknolojileri ve materyallerinin kullanılması işe koşulan duyu organlarını artırmakta ve üst düzeyde öğrenmenin gerçekleşmesini sağlamaktadır (İnel ve Sezer, 2017). Dolayısıyla öğretmenin sınıfa konuya ilişkin materyal getirmesi, öğretme-öğrenme süreçlerini destekleyen, çeşitlendiren ve zenginleştiren bir uygulama olarak değerlendirilebilir. Diğer yandan Bay Lazhar filmindeki öğretmenin, sınıfın seviyesine uygun olmayan bir metni derste okutmasının ise öğretimsel düzenlemeyi olumsuz etkileyen bir uygulama olduğu düşünülmektedir. Öğrencilerin yaş ve gelişim özellikleri, motivasyonlarını doğrudan etkileyen önemli bir faktör olarak (Eren Uğurlu, 2018) düşünüldüğünde, öğretmenin öğrencilerin seviyesine uygun olmayan bir metni derste okutmasının öğrenci motivasyonuna olumsuz etkileri olabileceği söylenebilir.

Zaman yönetimi, ihtiyaçlara yönelik tespit edilen hedeflerin kullanılabilecek zaman dilimi içerisinde gerçekleştirilmesi anlamına gelmektedir (Bozbayındır, 2019). Sınıfta ders süresini verimli biçimde kullanması, öğretmenin en önemli mesleki sorumluluk ve yeterlik göstergesidir (Aydın, 2017). Aynı zamanda Gage, Scott, Hirn ve MacSuga-Gage (2018) etkili sınıf yönetiminin kritik bileşenlerinden biri olan zamanı verimli kullanmanın öğrenci başarı üzerinde de etkili olduğunu belirtmişlerdir. Dolayısıyla, sözü edilen bu hedeflerin sınırlı zaman dilimi içerisinde gerçekleştirilebilmesinin ilk adımı ise öğretmenin derse hazırlıklı gelmesidir. Ölü Ozanlar Derneği adlı filmde öğretmenin derse gelmeden önce kayda değer bir hazırlık yaptığı anlaşılmaktadır. Öğretim etkinlikleri öğretmenler tarafından planlandığında, zaman kaybı önlenmiş olur (Eren Uğurlu, 2018), ders içinde istenmeyen davranış örüntülerinin önüne geçilir (Yolcu, 2015) ve kullanılan ders süresi daha verimli hale gelir (Toprakçı, 2017). Diğer yandan, öğretmenin plansız bir şekilde derse girmesi sınıf içerisinde kargaşanın yaşanmasına ve istenmeyen öğrenci davranışlarının ortaya 
çımasına neden olabilir. Örneğin; İki Dil Bir Bavul filminde derse plansız bir şekilde gelen öğretmenin tek öğrenciyle ilgilendiği, diğer öğrencilerin ise ders dışı aktivitelerde bulunduğu görülmektedir. Bu durumun, diğer öğrenciler için öğretmen tarafından herhangi bir etkinliğin planlanmamasına bağlı olduğu düşünülmektedir. Benzer şekilde Bay Lazhar adlı filmde öğretmenin ders materyallerini ders öncesinde hazırlamadığı görülmektedir. Öğretmenin derse hazırlıklı gelmesi ve ders öncesinde materyalleri hazırlaması, öğrencilerin derse yönelik motivasyonunu artırmakta (Sürücü ve Ünal, 2018) ve sınıfta ortaya çıkabilecek birçok sorunun önlenmesini sağlamaktadır (Çelik, 2021). Bununla birlikte öğretmenin ders için ayrılan süreyi verimli kullanabilmesi derse zamanında girmesi ile doğrudan ilişkilidir. Sınıf adlı filmde öğretmenin öğrencileri sınıfın kapısında karşılaması hem zamanı verimli kullanması hem de öğrencilerine rol olması açısından çok önemli bir davranıştır. Boyraz ve Kocabaş (2018) tarafından yapılan çalışmada da, öğretmenlerin zamanı etkili kullanabilmek için derslere zamanında başlamaya özen gösterdikleri belirlenmiştir. Öğretmenlerin derslere hazırlıklı ve zamanında gelmelerinin, öğretmenlik meslek etiği açısından da oldukça bir davranış olduğu söylenebilir (Karataş, Caner, Kahyaoğlu ve Kâhya, 2019).

Sınıf yönetimi ve öğrenme süreci açısından öğretmen ile öğrenci arasındaki iletişimin niteliği büyük önem taşır (Hoşgörür, 2019). Araştırmada incelenen filmlerde yer alan öğretmenlerin öğrencileriyle olan iletişim ve etkileşimlerinin genel olarak pozitif ve öğrenme süreçlerini destekleyici olduğu söylenebilir. Filmlerde yer alan öğretmenler sakin, samimi, ben dili kullanan, nezaket kurallarına dikkat eden ve beden dilini etkili kullanan yapıdadırlar. Aynı zamanda, öğrencilerle konuşurken göz teması kurmakta, öğrencilere isimleriyle hitap etmekte, onlara söz hakkı tanımakta ve gerekli dönütleri vermektedirler. Erwin'e (2003) göre öğrenciler, öğretmenlerinin sakin ve nazik bir şekilde konuşmasını istemekte çünkü bu durum öğrencilere kabul edildikleri mesajını vermektedir. Sözlü iletişimin yanında öğretmenin beden dilini etkili bir şekilde kullanması da öğrenci ile iletişimini pozitif yönde etkilemektedir. Öğretmenlerin öğrencileri ile göz teması kurmaları; onlara değer verdiğini hissettirmesi (Düzgün ve Selçuk, 2018), öğrencilerin derse ilgilerini sürdürmeyi sağlaması (Çalışkan ve Yeşil, 2005) ve istenmeyen öğrenci davranışlarını önlemesi (Girmen, Anılan, Şentürk ve Öztürk, 2006) açısından önem taşır. Bunlara ek olarak isim ile hitap etme ve söz hakkı tanıma ise öğrencilere ve onların düşüncelerine değer verildiğini gösteren, öğrencilerle iletişim sürecini kolaylaştıran ve geliştiren önemli becerilerdir. Aynı zamanda öğrencilere isim ile hitap etmenin, istenmeyen davranışları önleme açısından kullanılan bir strateji olduğu da belirlenmiştir (Özer, Bozkurt ve Tuncay, 2014).

Sınıf ortamında istenmeyen davranış, öğrencilerin öğrenmesini olumsuz etkileyen ve öğrencilerin kasıtlı veya kasıtsız olarak gösterdikleri davranışlardır (Celep, 2014). Etkili bir sınıf yönetimi için, eğitim öğretim etkinliklerinin yürütülmesinde sorun oluşturan istenmeyen davranışları ortadan kaldırılması (Avcı, 2019) ve tüm çocuklar için öğrenme olanaklarının en üst düzeye çıkarıldığı güvenli ve destekleyici bir eğitim ortamı yaratılması gerekir (Evertson ve Emmer, 2009). İstenmeyen davranışların önlenmesinde ve ortadan kaldırılmasında aktif bir rol üstlenmesi gereken öğretmen, benzer şekilde istenen davranışların ortaya çıkmasında ve sürdürülmesinde de mesleğinin gereği olarak sorumluluk almalıdır. Bu araştırma kapsamında incelenen filmlerde yer alan öğretmenler ortaya çıkan olumsuz davranışların çözümü konusunda farklı yaklaşımlar sergilemiştir. Örneğin Ölü Ozanlar Derneği filminde yer alan öğretmen, ortaya çıkan olumsuz davranışa sakin ve soğukkanlı bir biçimde yaklaşarak problemli davranışın ortadan kaldırılmasını sağlamıştır. Eğitimde istenen davranışların ortaya çıkması belli bir süreci gerektirmektedir. Bu açıdan öğretmenin istenmeyen davranışlar karşısında öfkelenmemesi, olumsuz duygularını bastırabilmesi, sakin ve sabırlı olabilmesi oldukça önemlidir (Başar, 2016). Bu açıdan Ölü Ozanlar Derneği filminde yer alan öğretmenin, sınıf yönetimi açısından doğru bir davranış sergilediği söylenebilir. İncelenen diğer filmlerde ise istenmeyen öğrenci davranışlarına yönelik öğretmenler tarafından ceza yöntemi kullanılmış ve sorunlarla ilgilenilmemiştir. Tepkisel sınıf yönetimi yaklaşımını benimseyen öğretmenler, istenmeyen öğrenci davranışlarını ödül ve ceza yoluyla kontrol altına almaya çalışmakta ancak bu yol öğretmen denetimini daha ön planda tuttuğu için öğrencilerin öz disiplin kazanmalarını engellemektedir (Altıntaş, 2016; Yumuşak ve Balcı, 2018). Öğretmenler cezadan çok önleyici yöntemlere başvurmalıdır (Başar, 2016).

Özetle, incelenen filmler sınıf yönetimi açısından olumlu ve olumsuz birçok uygulamayı içerisinde 
barındırmaktadır. Bu bağlamda, filmlerdeki öğretmenlerin davranışları eleştirel bir bakış açısıyla değerlendirilerek izleyenlere olumlu ve olumsuz örnekler sunabilecek niteliktedir. Dolayısıyla eğitim içerikli filmlerin öğretmen adaylarının öğretmenlik mesleğine yönelik tutumlarını önemli bir şekilde etkileyebileceği düşünülmektedir. Öğretmen adaylarının eğitildiği Eğitim Fakültelerinde; Eğitime Giriş, Sınıf Yönetimi, Türk Eğitim Sistemi ve Okul Yönetimi vb. derslerde filmlerin kullanılması, öğretmen adaylarının yansıtıcı düşünce becerilerini güçlendirebilir. Aynı zamanda filmler, öğretmen adayları için sınıf ortamını analiz etmelerini ve keşfetmelerini sağlayabilir. Bu görsel öğrenme tarzı ile öğretmen adayları, içerisine öğrencilerin yaşamları ile ilgili kavramlar ve teoriler koyarak farklı bakış açıları ile gerçek yaşam deneyimleri geliştirebilir (Fennell, 2013; Kontaş, 2016; Tofur, 2018). Bu bakımdan eğitim içerikli filmlerin analizlerinin ve inceleme çalışmalarının daha fazla önemsenmesi ve yaygınlaştırılması gerektiği düşünülmektedir. Bu araştırmada eğitim içerikli filmler sınıf yönetiminin boyutları açısından incelenmiştir. Filmlerin doğası gereği etki alanı çok geniş olduğundan dolayı filmler, yapılacak olan farklı eğitim araştırmalarına konu olabilir ve önemli bir veri kaynağı olarak kullanılabilir.

\section{Yazar(lar)ın Beyanı}

Araştırmacıların katkı oranı beyanı: Verilerin toplanması, verilerin analizi, raporlaştırma, araştırmanın tasarlanması ve veri toplama aracinın oluşturulması aşamalarında Birinci ve İkinci yazar etkin bir rol üstlenmiştir.

Etik Kurul Kararı: Bu araştırmada doküman incelemesi yöntemi kullanılmıştır. Bu nedenle araştırma, etik kurul kararından muaf olup araştırma ve yayın etiğgine uygun olarak gerçekleştirilmiştir.

Çatışma beyanı: Makalenin yazarları bu çalışma ile ilgili taraf olabilecek herhangi bir kişi ya da finansal ilişkileri bulunmadı̆̆ını dolayısıyla herhangi bir çıkar çatışmasını olmadığını beyan ederler.

Destek ve teşekkür: Çalışmada herhangi bir kurum ya da kuruluştan destek alınmamıştır.

\section{Kaynaklar}

Akcan, E. \& Polat, S. (2016). Eğitim konulu Türk filmlerinde öğretmen imajı: Öğretmen imajına tarihi bakış. Kuram ve Uygulamada Eğitim Yönetimi Dergisi, 22(3), 293-320.

Akcan, E. (2018). Simıfinda kaynaştırma öğrencisi olan ve olmayan simıf öğretmenlerinin sinıf yönetimi davranışlarının karşılaştırılması. (Yayımlanmamış Doktora tezi). İstanbul Üniversitesi, İstanbul.

Akgün, E., Yarar, M. \& Dinçer, Ç. (2011). Okul öncesi öğretmenlerin sınıf içi etkinliklerde kullandıkları sınıf yönetimi stratejilerinin incelenmesi. Pegem Ĕ̆itim ve Öğretim Dergisi, 1(3), 1-9.

Akın, A. \& Koçak, R. (2007). Öğretmenlerin sınıf yönetimi becerileri ile iş doyumları arasındaki ilişki. Kuram ve Uygulamada Ĕ̆itim Yönetimi, (51), 353-370.

Altıntaş, M. E. (2016). Tepkisel ve gelişimsel sınıf yönetimi modellerinin ahlak eğitimiyle ilişkisi. Bilimname, $30(1), 207-221$.

Altunışık, R., Coşkun, R., Bayraktaroğlu, S. \& Yıldırım, E. (2010). Sosyal bilimlerde araştırma yöntemleri (6. Baskı). Sakarya: Sakarya Yayıncılık.

Atkinson, R.L., Atkinson, R.C. \& Hilgard, E.R. (1995). Psikolojiye giriş II. İstanbul: Sosyal Yayınlar.

Avcı, Y. E. (2019). Davranış/ilişki düzenlemeleri (İstenmeyen davranışlar ve disiplin). O. Sarı̈öz, R. Tösten \& M. Baş (Edt.), Sınıf yönetimi içinde (ss. 165-178). Ankara: Anı Yayıncılık.

Aydın, A. (2017). Sinıf yönetimi. (19. Baskı). Ankara: Pegem Akademi Yayıncılık.

Bakioğlu, A. (2009). Çă̆daşs sınıf yönetimi. Ankara: Nobel Yayıncılık.

Balyer, A. (2018). Sınıf yönetimi. İstanbul: Efe Akademi Yayıncılık.

Başar, H. (2009). Sınıf yönetimi. (15. Baskı). Ankara: Anı Yayıncılık. 
Başar, H. (2016). Sınıf yönetimi (20. Baskı). Ankara: Anı Yayıncılık.

Birkök, M. C. (2008). Bir toplumsallaştırma aracı olarak eğitimde alternatif medya kullanımı: Sinema filmleri. Uluslararası İnsan Bilimleri Dergisi, 5(2), 1-12.

Boyraz, M. \& Kocabaş, İ. (2020). İlkokul öğretmenlerinin zaman yönetimi becerilerinin belirlenmesi. Yıldız Sosyal Bilimler Enstitüsü Dergisi, 2(1), 42-57.

Bozbayındır, F. (2019). Sınıfta zaman yönetimi. O. Sarı̈öz, R. Tösten \& M. Baş (Edt.), Sınıf yönetimi içinde (ss. 101-134). Ankara: Anı Yayıncilık.

Böke, K. (2014). Sosyal bilimlerde araştırma yöntemleri. İstanbul: Alfa Yayıncıllk.

Buchanan, D. \& Huczynski, A. (2004). Images of influence: 12 angry men and thirteen days. Journal of Management Inquiry, 13(4), 312-323.

Burbach, H. J. \& Figgins, M. A. (1993). A thematic profile of the images of teachers in film. Teacher Education Quarterly, 20(2), 65-75.

Cangelosi, J. S. (2016). Sınıf yönetimi stratejileri: Öğrencilerin iş birliği yapmalarmı sağlama ve bu iş birliğini devam ettirme (Çev. R. Hoş \& M. Toprak). Ankara: Nobel Yayıncılık.

Celep, C. (2014). Sinıf yönetiminde kuram ve uygulama (7. Basım). Ankara: Nobel Yayıncilık.

Çakmak, M., Kayabaşı, Y. \& Ercan, L. (2008). Öğretmen adaylarının sınıf yönetimi stratejilerine yönelik görüşleri. Hacettepe Üniversitesi Ĕ̆itim Fakültesi Dergisi, (35), 53-64.

Çalışkan, N. \& Yeşil, R. (2005). Eğitim sürecinde öğretmenin beden dili. Gazi Üniversitesi Kırşehir Eğitim Fakültesi Dergisi, 6(1), 199-207.

Çelik, Y. (2021). Öğretmenlerin zaman tuzaklarına düşmelerine ilişkin öğretmen adaylarının izlenimleri. Trakya Eğitim Dergisi, 11(1), 464-481.

Çubukçu, Z. \& Girmen, P. (2008). Öğretmenlerin sınıf yönetimi becerilerine ilişkin görüşleri. Bilig, (44), 123142.

Dalton, M. M. (1995). The Hollywood curriculum: Who is the 'good' teacher? Curriculum Studies, 3(1), 23-44,

Dalton, M. M. (2013). Bad teacher is bad for teachers. Journal of Popular Film and Television, 41(2), 78-87.

Denizel Güven, E. \& Cevher, F. N. (2005). Okul öncesi öğretmenlerinin sınıf yönetimi. Pamukkale Üniversitesi Eğitim Fakültesi Dergisi, (18), 1-22.

Düzgün, S. \& Selçuk, Z. (2018). Sözsüz iletişim becerilerinden öğretmenlerin öğrencilerle göz teması kurma davranışlarının bazı değişkenler açısından değerlendirilmesi. Erciyes İletişim Dergisi, 5(4), 771-795.

Efendioğlu, E. (2013). Türk sinemasında öğretmen imajı. (Yayımlanmamış yüksek lisans tezi). Yeditepe Üniversitesi, İstanbul.

English, F. W. \& Steffy, B. E. (1997). Using film to teach leadership in Educational Administration. Educational Administration Quarterly, 33 (1), 107-115.

Epstein, Y. M., Rosenberg, H. S. \& Smith, J. K. (1991). The image of the teacher in film. American Psychological Association, 16-20. https://eric.ed.gov/?id=ED340066

Eren Uğurlu, Z. (2018). Öğretim sürecinin yönetimi. A. O. Demirbolat (Edt.), Sinıf yönetimi içinde (ss. 93-178). Ankara: Pegem Akademi.

Erwin, J. C. (2003). Giving students what they need. Educational Leadership, 61(1), 19-23.

Evertson, C. M. \& Emmer, E. T. (2009). Classroom management for elementary teachers. London: Pearson. 
Eğitim Konulu Filmlerin Sınıf Yönetiminin Boyutları...

Fennell, H. A. (2013). Reel stories of teaching: Film and teacher education. Action in Teacher Education, 35(5-6), $445-461$

Finn, J. D. \& Achilles, C. M. (1990). Answers and questions about class size: A statewide experiment. American Educational Research Journal, 27(3), 557-577.

Gage, N. A., Scott, T., Hirn, R. \& MacSuga-Gage, A. S. (2018). The relationship between teachers' implementation of classroom management practices and student behavior in elementary school. Behavioral Disorders, 43(2), 302-315.

Garrett, T. (2014). Effective classroom management: The essentials. New York: Teachers College Press.

Gazetas, A. (1992). The image of a teacher as a romantıc rebel in narrative film. (Yayımlanmamıs Doktora tezi). The University of British Columbia.

Gilbert, L. A. (2014). Cinematic representations of female teachers: A narratological analysis of mise-en-scene in recent Hollywood films. (Yayımlanmamış Doktora Tezi), Northern Illinois University De Kalb, Illinois.

Gilberts, G. H. \& Lignugaris-Kraft, B. (1997). Classroom management and instruction competencies for preparing elemantary and special education teachers. Teaching and Teacher Education, 13(6), 597-610.

Girmen, P., Anılan, H., Şentürk, İ., \& Öztürk, A. (2006). Sınıf öğretmenlerinin istenmeyen öğrenci davranışlarına gösterdikleri tepkiler. Manas Üniversitesi Sosyal Bilimler Dergisi, 8(15), 235-244.

Glanz, J. (1997). Images of principals on television and in the movies. The Clearing House, 70(6), 295-298.

Gonzalez, B. P., Graziela, M., Gonzalez, B. M., Rozenfeld, L. M. \& Aurelio, J. M. (2015). Education through Movies: Improving teaching skills and fostering reflection among students and teachers. Journal of Learning through the Arts, 11(1). 1-18.

Grobman, D. J. (2002). Teachers in film: a narrative study of school teachers in cinema. (Yayımlanmamış Doktora tezi). Harvard University, Cambridge.

Grunder, H. U. (2016). The image of teachers: The perception of others as impulses for the professionalisation of teaching. British Journal of Religious Education, 38(2),152-162.

Hauseman, D. C. (2010). Media portrayals of the principalship and their influence on current school leaders. (Yayımlanmamış doktora tezi). Nipissing University Faculty Of Education North Bay, Ontario.

Hill, M. R. (1993). Archival strategies and techniques. California: Sage Publications

Hooks, B. (2009). Reel to Real: Race, class and sex at the movies. New York: Routledge Publishing.

Hoşgörür, V. (2019). İletişim. Z. Kaya (Edt.), Sınıf yönetimi (17. Baskı) içinde (ss. 151-182). Ankara: Pegem Akademi.

Huczynski, A. \& Buchanan, D. (2004). Theory from fiction: A narrative process perspective on the pedagogical use of feature film. Journal of Management Education, 28(6), 707-726.

Işık, H. (2020). Öğrenme ortamlarının fiziksel düzeni. M. Şişman \& S. Turan (Edt.), Sınıf yönetimi (20. Baskı) içinde (ss. 62-79). Ankara: Pegem Akademi.

İlgar, L. (2007). İlköğretim öğretmenlerinin sımı yönetimi becerileri üzerine bir araştırma (Yayımlanmamış Doktora Tezi). İstanbul Üniversitesi, İstanbul.

İnel, Y. \& Sezer, A. (2017). Coğrafya konuların öğretiminde materyal kullanımının öğrenci başarısına etkisi: Bir meta analiz çalışması. Journal of History Culture and Art Research, 6(3), 473-491.

Jowett, G. S., Jarvie, I. C. \& Seeley-Fuller, K. (1997). Children and the movies: Media influence and the payne fund controversy. Cambridge: Cambridge University Press.

Judge, H. (1995). The images of teachers. Oxford Review of Education, 21(3), 253-265. 
Karataş, S., Caner, M., Kahyaoğlu, R. B. \& Kâhya, S. (2019). Öğretmen adaylarının gözünden etik öğretmen ve öğretmenlik meslek etiği dersi. Eğitimde Nitel Araştırmalar Dergisi, 7(1), 29-49.

Karataş, Z. (2015). Sosyal bilimlerde nitel araştırma yöntemleri. Manevi Temelli Sosyal Hizmet Araştırmaları Dergisi, 1(1), 62-80.

Karip, E. (2017). Sinıf yönetimi. Ankara: Pegem Akademi.

Kaşkaya, A., Ünlü, İ., Akar, M. S. \& Özturan-Sağırlı, M. (2011). Okul ve öğretmen içerikli sinema filmlerinin öğretmen adaylarının mesleki tutumlarına ve öz yeterlik algılarına etkisi. Kuram ve Uygulamada Eğitim Bilimleri, 11(4), 1765-1783.

Kontaş, H. (2016) The effect of an education-themed movie on the academic motivation of teacher candidates and their attitude towards teaching profession. Journal of Education and Training Studies, 4(6), 93-103.

Mac Donald, R. E. \& Healy, S. (1999). A handbook for beginning teachers. New York: Addison Wesley Longman Inc.

Mauer, E. E. (1998). Perceived images of school administrators as portrayed in feature films 1960-1993. (Yayımlanmamış Doktora tezi). Loyola University, Chicago.

McCambridge, J. (2003). 12 angry men: A study in dialogue. Journal Of Management Education, 27(3), 384-401.

Metzger, A. S. (2010). Maximizing the educational power of history movies in the classroom. The Social Studies, 101(3), 127-136.

Millî Eğitim Bakanlı̆̆ı. (2018). Örnek film listesi. https://oygm.meb.gov.tr/meb iys dosyalar/2018 09/17153259 FYLM LYSTESY 17.09.2018 .pdf

Nederhouser, D. D. (2000). Reel teachers: A descriptive content analysis of The portrayal of American teachers in popular cinema. (Yayımlanmamış Doktora tezi). Northern Illinois University, DeKalb.

Novello, M. A. (1994). The school administrator in popular film. (Yayımlanmamış Doktora tezi). Drake University, Des Moines.

Oruç, Ş. \& Sarıbudak, D. (2015). Okul yöneticilerinin ve öğretmenlerin eğitim içerikli filmlerin eğitim ortamlarına etkisine ilişkin görüşleri. International Journal of Field Education, 1(1), 19-41.

Özdemir, M. (2016). Veri analiz yöntemleri: Nicel ve nitel veri analizi. K. Beycioğlu, N. Özer \& Y. Kondakçı (Edt.), Eğitim yönetiminde araştırma içinde (ss. 133-167). Ankara: Pegem Akademi.

Özer, B., Bozkurt, N., \& Tuncay, A. (2014). İstenmeyen öğrenci davranışları ve öğretmenlerin kullandıkları başa çıkma stratejileri. Turkish Journal of Educational Studies, 1(2), 152-189.

Özkan, H., Arslan, M. C. \& Kara, M. (2014). Popüler kültürün öğrenci davranışları üzerinde algılanan etkileri. Ekev Akademi Dergisi, 18(58), 469-484.

Polat, S. \& Akcan, E. (2017). Eğitim temalı filmlerin çokkültürlü eğitim açısından analizi. Electronic Turkish Studies, 12(18), 474-504.

Sadık, F. (2000). İlköğretim 1.aşama sınıf öğretmenlerinin sınıfta gözlemledikleri problem davranışlar. (Yayımlanmamış Yüksek Lisans Tezi). Çukurova Üniversitesi. Adana.

Sayın, N. (2001). Sını öğretmenlerinin karşılaştıkları istenmeyen öğrenci davranışları ve bu davranışların nedenlerine ilişkin görüşleri ile istenmeyen davranışları önleme yöntemleri. (Yayımlanmamış Yüksek Lisans Tezi). Anadolu Üniversitesi, Eskişehir.

Serey, T. T. (1992). Carpe Diem: Lessons about life and managemet from Dead Poets Society. Journal of Management Education. 16(3), 374-381.

Smith, M. R. (2003). Images of school teachers in America. Peabody. Journal of Education, 78(1), 102-107. 
Sürücü, A. \& Ünal, A. (2018). Öğrenci motivasyonunu artıran ve azaltan öğretmen davranışlarının incelenmesi. OPUS Uluslararası Toplum Araştırmaları Dergisi, 8(14), 253-295.

Swift, D. W. (1974). Situations and stereotypes: Variations in the school administrator's role. The Elementary School Journal, 75(2), 69-78.

Tan, A. G. A. (1999). The image of teachers in film. (Yayımlanmamış Doktora tezi). Boston College, Massachusetts.

Thomas, A. R. (1998). As they are portrayed: Principals in film. The International Journal of Educational Management, 12(2), 90-100.

Tofur, S. (2018). Case of a classroom management model in cinematographic narration: The movie "Stand and Deliver". International Online Journal of Educational Sciences, 10(2), 146-161.

Toprakçı, E. (2017). Sınıf yönetimi (3. Bask1). Ankara: Pegem Akademi.

Townsen, J. S. \& Ryan, P. A. (2012). Media narratives and possibilities for teachers' embodied concepts of self. The national association for media literacy education's. Journal of Media Literacy Education, 4(2), 149-158.

Trier, J. D. (2001). Exploring the Cinematic Representation of Teachers, Students, and Schools with Preservice Teachers. (Yayımlanmamış Doktora tezi). University of Wisconsin-Madison, Madison.

Üstün, A., Nural, E. \& Değer, Ş. (2005). Ortaöğretim öğretmenlerinin sınıfta zaman yönetimine ilişkin görüşlerinin değerlendirilmesi: Trabzon ili örneği. Abant İzzet Baysal Üniversitesi Eğitim Fakültesi Dergisi, 5(1), 47-66.

Weber, S. \& Mitchell, C. (1995). That's funny, you don't look like a teacher! Interrogating images and identity in popular culture. London, UK: Falmer Press.

Wolfrom, K. J. (2010). Reel principals: A descriptive content analysis of the images of school principals depicted in movies from 1997-2009. (Yayımlanmamış Doktora tezi). Indiana University of Pennsylvania.

Yaylagül, L. (2004). Yarışma programları ve ideolojisi. Bilim ve Aklın Aydınlı̆̆ında Eğitim, 5(57), 180-188.

Yıldırım, A. \& Şimşek, H. (2016). Sosyal bilimlerde nitel araştırma yöntemleri (10. Bask1). Ankara: Seçkin Yayınevi.

Yıldırım, N. (2019) Sınıfın fiziksel düzenini oluşturma. R. Sarpkaya (Edt.), Sınıf yönetimi içinde (ss. 59-78). Ankara: Anı Yayıncilık.

Yolcu, H. (2015). Sınıf yönetimini etkileyen etmenler. C. Gülşen (Edt.), Kuram ve uygulamada sınıf yönetimi içinde (ss. 23-59). Ankara: Anı Yayıncılık.

Yumuşak, G. \& Balcı, Ö. (2018). Öğretmenlerin istenmeyen öğrenci davranışları ile başa çıkma yöntemleri ve bu yöntemlerin etkililiğine ilişkin görüşleri. Balkkesir Üniversitesi Sosyal Bilimler Enstitüsü Dergisi, 21(40), 223-254. 


\section{EXTENDED ABSTRACT}

\section{Introduction}

The ultimate goal of an effective classroom management is prevention of the possible problems that may hinder teacher-student interaction and finding solutions to the problems that may emerge during classroom educational activities, efficient time management and active student participation in other classroom educational activities. To summarize, the main goal of classroom management is to create an effective and productive learning atmosphere in the classroom (Bakioğlu, 2009; Sadık, 2000; Sayın, 2001). However, it is not possible to create this atmosphere in a haphazard and unplanned manner. Management is multidimensional. Therefore, there are dimensions that make up classroom management. The literature mentioned five dimensions making up classroom management (Akcan, 2018; Aydın, 2017; Balyer, 2018). These dimensions are physical organization of the classroom, plan-programme activities, time management, relationship regulations and behavior regulations.

In the studies on classroom management (Akcan, 2018; Akgün, Yarar and Dinçer, 2011; Akın and Koçak, 2007; Çakmak, Kayabaşı and Ercan, 2008; Çetin, 2001; Çubukçu and Girmen, 2008; Denizel- Güven and Cevher, 2005), data were generally collected through teacher views or classroom observations. However, these methods have several limitations. For example, in order to portray himself/herself perfect, the teacher can talk about something that he/she did do even he/she did not do or vice versa. Similarly, the teacher, who is aware that he/she is being watched during in-class observations, may not act naturally. Due to these limitations, it was necessary to use different methods in some studies on classroom management. Movie research is one of these methods.

Recently, movies have a pedagogical position that also brings along learning to societies. Although most movie scripts are not turned into movies by producers and directors with the concern of "teaching", it is believed that the audience learns a lot from movies they watch without even realizing it (Hooks, 2009). Teachers who watch movie scenes in which positive teacher images are displayed can develop positive attitudes (Kaşkaya, Ünlü, Akar and Özturan-Sağırlı, 2011). In addition to attitudes, with their portrayal of characters in the movies, movies can contribute to the audience in terms of many factors, not just attitudes (Gilbert, 2014). Moreover, a lot can be learned about educational institutions and their stakeholders through movies. For this reason, it is not surprising that movies address education-related issues, and that educational research focuses on movies.

The purpose of the present study was to analyze the classroom management behaviors of teachers in the movies recommended by the MoNE for teachers to watch during the September 2018 professional work programme.

\section{Method}

In this study, qualitative research method was preferred because the study aimed to explore and interpret voluminous materials. Descriptive analysis was employed to reach concepts and relationships that could explain the data collected in qualitative research. In order to collect the data, the document analysis technique was deemed appropriate.

The study material consisted of education-related movies. For this purpose, four movies, which were appropriate for the present study's purpose, were selected among the 50 movies recommended by the MoNE during the September 2018 professional work programme that aimed to increase the knowledge and experience of the administrators and teachers working in preschools, elementary, middle and high schools in the fields of general culture, special field education and pedagogical formation, to teach new skills, to find solutions to the problems encountered in teaching, and to prepare plans and programs according to the needs of the students and the environment (MoNE, 2018). In the study, criterion sampling technique, one of the purposeful sampling methods, was employed. The criterion sampling technique involves the examination of the material to be sampled by considering various criteria determined beforehand by the researchers in accordance with the study purpose (Yıldırım and Şimşek, 2016). In other words, it refers to the 
selection of situations with characteristics compatible with the study purpose of the study as the study sample. In this way, it helps to gather similar situations that the researcher examined in his/her study under the same headings (Böke, 2014).

To ensure and increase the validity of the study, the whole process from the first step to the last stage of the study is explained in detail. In addition, the findings were presented together with movie frames and direct quotations, and supported with justifications by comparing them with other studies in the literature. For the reliability of the study, during the analysis process of the movies, both researchers examined the movies at different times and places and recorded their findings with the help of observation forms without wasting time. Then, two researchers examined the same movies together and compared the results they had previously recorded. Similar findings were assessed as they were, and a consensus was reached on the different findings by discussing them. In this way, the percentage of agreement was also calculated. The percentage of agreement was calculated by rating the observed classroom management behaviors with the agreed results.

\section{Results and Conclusion}

The movies examined contained many positive and negative practices in terms of classroom management. In this context, the behaviors of the teachers in the movies can be assessed from a critical point of view and present positive and negative examples to the audience. Therefore, it is believed that movies with educational content can significantly affect teacher candidates' attitudes towards the teaching profession. Using movies in Introduction to Education, Classroom Management, Turkish Education System and School Management courses in the education faculties where teacher candidates are trained can strengthen the reflective thinking skills of teacher candidates. Furthermore, movies can enable teacher candidates to analyze and explore the classroom environment. With this visual learning style, teacher candidates can develop real-life experiences with different perspectives by including concepts and theories about students' lives (Fennell, 2013; Kontaş, 2016; Tofur, 2018). In this respect, it is believed that the analysis and examination studies of educational movies should be given more importance and popularized. In this study, movies with educational content were examined in terms of the dimensions of classroom management. Since the sphere of influence of the movies is quite wide due to their nature, they can be the subject of different educational studies and can be used as an important data source. 